\title{
TANULMÁNYOK
}

\section{Területi különbségek a hazai népesség egészségi állapotában, 1989 után}

\section{Regional differences in the health state of the Hungarian population after 1989}

\author{
Kiss Éva A rendszerváltozás óta a magyar népesség egészségi \\ MTA CSFK állapotában jelentős változások mentek végbe, ame- \\ Földrajztudományi Intézet \\ lyek a térben is tükröződnek. Tanulmányunkban \\ E-mail: \\ kisse@helka.iif.hu \\ arra a kérdésre keressük a választ, hogy hogyan vál- \\ tozott a jobb és a rosszabb egészségi állapotú terüle- \\ tek földrajzi megoszlása az elmúlt évtizedekben. \\ A fontosabb egészségmutatókat három időpontban \\ (1992, 2000, 2014) és megyei szinten elemeztük. \\ Nyilvánvalóvá vált, hogy a rendszerváltozás után \\ nemcsak a területi különbségek mértéke módosult, \\ hanem a jobb vagy a rosszabb egészségi állapotú te- \\ rületek térbeli mintázata is, amit - sok egyéb tényező \\ mellett - az örökölt területi különbségek is befolyá- \\ soltak. Az 1990-es évektól napjainkig az a leglénye- \\ gesebb változás, hogy eltolódás következett be a leg- \\ jobb és a legrosszabb egészségi állapotú területek el- \\ Kulcsszavak: helyezkedésében. Az előbbiek súlypontja áthelyező- \\ egészségi állapot, dött az Észak-Dunántúlról Közép-Magyarországra, \\ területi különbségek, míg az utóbbiak napjainkra erősebben kapcsolódnak \\ halálozás, Észak-Magyarország térségéhez és az Alföld kö- \\ Magyarország zépső részéhez.
}


Since the change in the political system relevant changes have taken place in the state of health of the Hungarian population. In this study the answer is looked for that question how the geographical pattern of areas with good and bad health changed during the last decades. The more important health indicators are analysed from different aspects at three different times and at county level. It has become obvious that after 1989 not only the measure of regional differences had been modified but also the spatial pattern of areas with favourable or unfavourable states of health that were affected by the regional differences inherited among many other factors. From 1990s until nowadays the most essential change that a shift has taken place in the geographical distribution of the areas with the best

Keywords: and worst health state. The centre of the former state of health, ones was relocated from Northern Transdanubia regional differences, to Central Hungary, while the latter ones are more death, strongly connected to Northern Hungary and the

Hungary middle part of Great Plain.

Beküldve: 2016. május 17.

Elfogadva: 2016. július 21.

\section{Bevezetés}

A népesség egészségi állapotában nemcsak az országok között vannak különbségek, hanem az országokon belül is. Az ENSZ Egészségügyi Világszervezetének felmérése szerint utóbbiak azért egyre nagyobb jelentőségűek, mert sokszor igen élesek, ezért a vizsgálatuk rendkívül fontos külföldön és idehaza egyaránt (Ambrus-Varsányi 2011, Kopp-Martos 2011, Pál-Uzzoli 2008, Uzzoli 2010). Az egészségi állapotban mutatkozó különbségek - többek között - az eltérő genetikai adottságokkal és az egyes „földrajzi helyek” eltérő társadalmi, gazdasági jellemzőivel magyarázhatók. Utóbbiak milyenségének, a földrajzi fekvésnek az elmúlt évtizedekben az egészségföldrajz egyre nagyobb szerepet tulajdonít az egészségi állapot meghatározásában (Bolam et al. 2006, Smyth 2008, Veenstra 2005). A ,helyet” olyan múködő, élő struktúrának tekintve, ami számít és fontos, szemben a passzív „konténer” funkcióval, amelyben a dolgok csak megnyilvánulnak és rögzülnek (Kearns-Moon 2002).

Területi Statisztika, 2016, 56(5): 483-519; DOI: 10.15196/TS560501 
Hazánkban a rendszerváltozás utáni politikai, gazdasági és társadalmi változások a regionális különbségek éleződését vonták maguk után (Enyedi 1993). Feltételezhetően ezek a változások befolyásolták a népesség egészségi állapotát is, ami 1989 után szintén régiónként különböző mértékben változott. Megyei szinten és három (1992, 2000, 2014) időpontban azt vizsgáljuk néhány egészségmutató (például a születéskor várható átlagos élettartam, a halálozások, a pszichiátriai gondozottak száma) alapján, hogy hogyan változott a hazai népesség egészségi állapotának területi különbsége a rendszerváltozás után. A fő kérdés az, hogy volt-e változás az egészségi állapot egyes indikátorainak földrajzi megoszlásában, azaz hogyan változott a területi különbségek térbeli mintázata az elmúlt negyedszázadban.

A tanulmány a bevezetést követően és az összefoglalást nem számítva hat fố részre tagolódik. Elóször a témaválasztáshoz kapcsolódó fontosabb fogalmakat és módszertani kérdéseket foglaljuk össze. Majd az egészségi állapotot meghatározó tényezők jelentőségét értékeljük a hazai és a külföldi szakirodalom felhasználásával. A harmadik fejezetben röviden áttekintjük a hazai népesség egészségi állapotát nemzetközi kontextusban, míg a negyedikben azt mutatjuk be, hogy milyen volt a rendszerváltozás elótti évtizedben, ugyanis az bizonyos fokig meghatározza az 1989 utáni folyamatokat is. Az ötödik fejezetben nyolc egészségmutatót, három különböző időpontban, megyei szinten vizsgálunk annak érdekében, hogy feltárjuk a jobb és a rosszabb egészségi állapotú területek változását. A hatodik fejezetben - más megközelítésben - szintén az egészségi állapot területi különbségeit elemezzük az egészségmutatók megyei értékei alapján képzett rangszámok kumulálása és kategorizálása révén.

\section{Fogalmak, adatforrások és módszertani kérdések}

A statisztikai kiadványok fogalmait alapul véve az egészségi állapot különbségeinek területi változásához használt mutatók közül a születéskor várható átlagos élettartam azt jelenti, hogy születéskor átlagosan hány évi élettartamra számíthatnak az újszülöttek. Ez a mutató közvetetten szintetikus indikátora a lakosság egészségi állapotát befolyásoló tényezőknek (életmód, életkörülmények, ellátórendszer, környezet állapota stb.). A megyei összehasonlítás során alapvetôen a nyers halálozási rátára támaszkodtunk, ami az ezer lakosra jutó meghaltak számát mutatja egy adott évben (Paulik 2014). A standardizált halálozási ráta az általános halálozási viszonyok nemzetközi összehasonlitására szolgál (KSH 2010). Kiküszöböli ugyanis a kormegoszlásból fakadó hatásokat, ami azért szükséges, mert a halálozásokat befolyásolja a népesség korösszetétele, továbbá éles különbségek lehetnek az egyes országok korstruktúrája között. A halálok pedig mindazon betegség, sérülés és kóros állapot, ami a halált kiváltotta vagy ahhoz hozzájárult. Vizsgálatunk középpontjába a fó halálokokat állítottuk.

Az egészségi állapot elemzésére kiválasztott indikátorok között szerepel egy morbiditási mutató, nevezetesen a pszichiátriai gondozottak tízezer lakosra jutó száma is, ami mellett több érv szólt. Vannak ugyan olyan további betegségek is (például mozgásszervi, anyagcserezavarok stb.), amelyek jelentős terhet rónak a társadalomra, és

Területi Statisztika, 2016, 56(5): 483-519; DOI: 10.15196/TS560501 
amelyek vizsgálata szintén fontos lenne az egészségi állapot minél pontosabb feltérképezéséhez. Azonban, részben terjedelmi korlátok miatt, részben azért, mert azok nem közvetlenül a mentális egészséget jelzik, ezért elemzésüktől tanulmányunkban eltekintünk. A pszichiátriai gondozottak tízezer lakosra jutó mutatója csak a ,jéghegy csúcsa”, mert nem „tartalmazza” az összes, valamilyen szempontból mentálisan sérült beteget. Egyrészt ugyanis sok az olyan pszichés problémával küszködő ember, aki nem jelenik meg az ellátórendszerben. Másrészt az is igaz, hogy a mutató nagymértékben függ olyan strukturális problémáktól, mint az ellátórendszer, a gondozói hálózat területi egyenlőtlenségei vagy éppen a diagnosztikai és ellátási protokoll elmúlt évtizedekbeli változásai. Mindezek figyelembevételével ezt az indikátort alkalmasnak tartjuk arra, hogy némi támpontot adjon a lelki egészség területi eltéréseiről, valamint hozzájáruljon az egészségi állapot teljesebb értékeléséhez.

A kiválasztott egészségmutatók adatait az említett három (1992, 2000, 2014) időpontra gyújtöttük ki a rendelkezésre álló hivatalos (demográfiai, egészségügyi és területi) statisztikai kiadványokból. A területi különbségek változásának feltárását a térszerveződés középszintjén végeztük el, mégpedig úgy, hogy a statisztikai adatokat térképen ábrázoltuk a 20 területi egységben (főváros és megyék). Ez volt az egyik alkalmazott módszertani megközelítés. Az ezekből összeállított ábrák jól szemléltetik azt, hogy az egyes mutatók esetében hogyan változott a jobb és a rosszabb értékekkel rendelkezô területek földrajzi megoszlása, továbbá azt is, hogy az elmúlt évtizedekben mennyire volt stabil a területi különbségek térbeli mintázata.

A tanulmányban alkalmazott másik módszertani megközelítéssel az egészségi állapot területi különbségeiben bekövetkezett változások pontosabb értelmezése érdekében egy komplex indexet hoztunk létre, a vizsgált évek megyei mutatói alapján képzett rangszámok kumulálásával. Az „,egészségrangsor” megállapításában egyes indikátorok kumulatív hatásának kiküszöbölése érdekében eltekintettünk az összes halálozás mint egészségmutató figyelembevételétől. Ezt az is lehetôvé tette, hogy a halálozások döntő hányadát (2014-ben 88,4\%-át) kitevő főbb halálokok miatti halálozások mint vizsgált indikátorok, szintén a vizsgálat részét képezték. Bár az így létrehozott komplex indexekben a vizsgált mutatók hatásának kumulálódása nem szűrhetô ki teljesen, mivel maguk az egyes indikátorok sem függetlenek egymástól, és az egyenkénti tényleges hatásukat sem könnyű meghatározni, ennek ellenére alkalmasak az egészségi állapot térbeli és időbeli különbségeinek bemutatására.

\section{Az egészségi állapotoł meghatározó tényezök}

Az egészségi állapotot meghatározó sokféle tényező - a Lalonde-jelentés (1974) szerint - alapvetően a következő négy fő́csoportba sorolható, zárójelben a befolyásuk százalékos mértéke az említett forrás, illetve Schmidt és szerzőtársai (2010) szerint:

- genetikai (örökölt) és szerzett adottságok (például életkor, nem) (27, 20\%),

- életmód, életvitel (táplálkozási szokások, egészségkárosító tényezők, sportolás stb.) $(43,35-40 \%)$, 
- a környezet (természeti, társadalmi, gazdasági környezet stb.) állapota (19, 25-30\%),

- egészségügyi ellátórendszer (egészségügyi intézményekhez való hozzáférés, felszereltség, ellátás színvonala stb.) (11,15\%).

Mivel a felsorolt tényezők előfordulása térben és időben differenciált, ezért befolyásuk mértéke is különböző, miáltal az egészségi állapot is változik helytől és időtől függően.

A négy tényezőcsoport közül az életmód befolyásolja a legnagyobb mértékben az egészségi állapotot, amiben egy 2009-ben végzett európai lakossági egészség felmérés (KSH 2015) szerint szintén jelentős regionális különbségek figyelhetők meg hazánkban. Általában a gazdaságilag fejlettebb dunántúli, illetve nyugati országrészek vannak jobb helyzetben ebből a szempontból (Ambrus-Varsányi 2011). Az életmód mellett még a születéstől fogva adott genetikai adottságokat tartják a legfontosabbnak az egészségi állapot megítélésében. A két tényezőcsoport együtt az egészségi állapot 60-70\%-áért „felelős”, ellenben a környezeti hatások és az egészségügyi ellátórendszer együttesen is „csak” 40-30\%-ban. Bár az egyes tényezőcsoportok tényleges hatását nehéz pontosan mérni, az kétségtelen, hogy az egyén életmódja, egészségtudatossága, egészséghez való viszonya stb. nagymértékben meghatározza az egészségi állapotát, ami viszont számtalan más tényező (például iskolai végzettség, életkor, foglalkozás stb.) eredője. Ilyen „háttértényezők”, amelyekből az egészségi állapotra következtethetünk, a többi csoportban is kijelölhetôk.

A gazdaság helyzetét, illetve területi egyenlőtlenségeit, amelyek tükröződnek a lakosság jövedelmi viszonyaiban, az életkörülményekben és a településhálózatban például a munkanélküliségi adatokkal vagy az egy főre jutó GDP területi megoszlásával jellemezhetjük (Enyedi 1993). A fejlett gazdaságú térségek népessége többnyire jó vagy jobb egészségi állapotú, mint a kevésbé fejlett, elmaradott gazdaságú területeké, amire már több kutatás is rámutatott (Egri 2012, Kiss 1993, Pál 2013, Uzzoli 2010).

A társadalmi-gazdasági fejlettség területi különbségei a válságok idején még inkább kiéleződnek, és kedvezőtlenül hatnak a népesség egészségi állapotára is. Az utóbbi évtized kutatásai azt tárták fel, hogy a gazdasági nehézségek következtében megugró munkanélküliség az a tényező, amely a leginkább negatívan befolyásolja az egészségi állapotot (Böckerman-Ilmakunnas 2008). A munkanélküliség tehát nem csak általában, hanem a gazdasági válságok idején különösen kedvezőtlen hatású. Ennél fogva releváns szerepe van az egészségegyenlőtlenségekben is. Magyarországon az 1990-es évek elején bekövetkezett válság és a 2008-ban kirobbant gazdasági válság egészségre gyakorolt hatásának vizsgálata is ezt erősítette meg (Szilágyi-Uzzoli 2013). Az egészségi állapot romlásához legfőképp és közvetve a munkaerőpiaci pozíció megváltozása (például munkanélkülivé válás) vezet, mert az kihat a jövedelmi viszonyokra, a fogyasztási szokásokra és végső soron az életkörülményekre, az életmódra is. Továbbá a lelki, a pszichés megbetegedések is gyakoribbá válhatnak a kilátástalanság, a felesle-

Területi Statisztika, 2016, 56(5): 483-519; DOI: 10.15196/TS560501 
gessé válás érzése, a szorongás, a stressz stb. miatt (Kopp-Skrabski 2001, Kopp-Martos 2011). Az is kimutatható ugyanakkor, hogy bár a legutóbbi válság az „új munkanélküliségen" keresztül a kedvezőbb helyzetú társadalmi csoportokat is hátrányosan érintette, jobb egészség-magatartási mutatóik miatt az nem rontotta az egészségi állapotukat (Szilágyi-Uzzoli 2013, Uzzoli 2012).

A társadalmi környezet állapota szintén sok, az egészségre is valamilyen mértékben hatással levő tényező (például kulturális-műveltségi színvonal, tradíciók, társadalmi struktúra) függvénye. Több kutatás is rámutatott arra, hogy az egyén társadalmi helyzete és egészségi állapota között szoros összefüggés van (Jones-Moon 1987, KoppSkrabski 2001, 2007, Miltényi 1991). Kiváltképp kedvezőtlen a lakosság egészségi állapota az ország társadalmi-gazdasági szempontból elmaradott, periférikus fekvésú térségeiben. A Közép-Tiszavidéken az 1990-es évek elején végzett kutatás például azt tárta fel, hogy az ott élők egészségi állapota az átlagosnál rosszabb. Főleg a társadalom perifériáján élő, a lakosság jelentős hányadát kitevő szegény sorsú, munkanélküli cigányság életkilátásai voltak nagyon kedvezőtlenek (akkor 10-15 évvel volt rövidebb születéskor várható átlagos élettartamuk a többi lakosnál) (Kiss 1993). Az ország egy másik hátrányos helyzetú térségében, az Ormánságban körülbelül két évtizeddel később végzett kutatás során azt tapasztalták, hogy bár a rossz egészségi állapot ott is köthető a romákhoz, a jó és a rossz egészségi állapot határa nem elsősorban etnikai alapú, hanem sokkal inkább annak a függvénye, hogy nincstelen vagy nem nincstelen, azaz munkanélküli vagy nem munkanélküli az illető (Pál 2013). Ez pedig azt a vélekedést erôsíti, hogy ma már a népesség egészségi állapotának különbségeit nem annyira a területi különbségek határozzák meg, hanem azok sokkal inkább a társadalmi helyzetből fakadnak. Másképpen kifejezve, nem annyira a lakóhely földrajzi elhelyezkedése a „döntő” az egészségi állapot szempontjából, hanem a társadalomban, a társadalmi hierarchiában elfoglalt pozíció, a társadalmi státus (Kopp-Skrabski 2007). Következésképp a legnagyobb törésvonal nem a térben van, hanem a különböző társadalmi rétegek között, vagyis a térbeli egyenlőtlenségnél fontosabb (lehet) a társadalmi egyenlőtlenség.

Az egészségügyi ellátórendszer területi differenciáit például az egy háziorvosra vagy az egy gyógyszertárra jutó lakosok számával jellemezhetjük. Az egészségügyi szolgáltatásokhoz való hozzáférés esélye függ a lakóhelytôl, pontosabban annak nagyságától, azaz a települési viszonyoktól is (Uzzoli et al. 2011). Rendszerint a nagyobb lélekszámú településeken többféle és magasabb szintű szolgáltatást biztosító egészségügyi intézmények vannak. Az egészségügyi létesítmények, illetve az egészségügyi szolgáltatások minőségében éles különbségek vannak a falvak és a városok között, és nemcsak idehaza, hanem külföldön is (Botan 2011, Platon-Constantinescu 2013). Az egészségügyi ellátás egyenlőtlenségei a rossz közlekedési kapcsolatokkal és a gyakran túl hosszú utazási idővel is magyarázhatók (Makara 1997). De a településnagyság mellett egyéb regionális különbségek is megfigyelhetők az ellátórendszerben, például a fejletlenebb, elmaradott térségekben gyakoribb a háziorvosi és a szakorvosi hiány.

Területi Statisztika, 2016, 56(5): 483-519; DOI: 10.15196/TS560501 
A Lalonde-jelentés (1974) óta az egészségi állapotot befolyásoló tényezőket sokféle összefüggésben és különféle módszerek alkalmazásával vizsgálták. Az elmúlt évtizedekben számos kísérlet történt az egészségegyenlőtlenségek okainak minél pontosabb meghatározására, ami együtt járt az egészséget befolyásoló tényezők fontosságának változásával is. Amíg Lalonde „health field” modellje az életmódra és a környezetre helyezte a hangsúlyt az egészségi állapot meghatározásában, addig a 20. század végétôl egyre nagyobb szerepet tulajdonítanak a társadalmi tényezőknek (lakóhely, faji, etnikai hovatartozás, foglalkozás, nemek szerinti megoszlás, vallási hovatartozás, iskolai végzettség, társadalmi-gazdasági helyzet, társadalmi tőke, társadalmi erőforrások) az egészségegyenlőtlenségben. Ezek röviden a „PROGRESS” szóval fejezhetők ki, ami angol megnevezésük első betújéből származik. Az életkor, a rokkantság és a szexuális orientáció ugyancsak kihat az egészségegyenlőtlenségre, amit „PROGRESSPlus"-ként említenek a szakirodalomban (Oliver et al. 2008). Mindezek a változások tükröződnek az újabb komplex egészségfejlesztési modellekben is (DahlgreenWhitehead 2006, Hamilton-Bhatti 1996). A rendszerszemléletú bio-pszicho-szociális modell szerint nemcsak a biológiai okokat, hanem a pszichológiai, szociális, kulturális és környezeti tényezőket is vizsgálni kell a betegségek kialakulásában (Pál-Uzzoli 2013). Nem egyetlen okot kell keresni, hanem a különböző okok komplex kölcsönhatását. A népesség egészségi állapotát tehát általában és egyénenként is nagyon sok tényező bonyolult kölcsönhatása határozza meg, amelyek direkt vagy indirekt módon fejtik ki hatásukat. Érvényesül a „,minden mindennel összefügg” elve. Ez pedig rendkívüli mértékben megnehezíti az egészségi állapot földrajzi különbségeit magyarázó okok pontos feltárását is.

\section{Nemzetközi kitekintés}

A posztszocialista országok népességének egészségi állapota alapvetően rosszabb, mint a fejlett országoké, holott ez a gazdasági fejlettségükből nem következik. Ez tulajdonképpen a közép-kelet-európai egészségparadoxon lényege (Cornia-Panicia 2000, Kopp-Skrabski 2007, Uzzoli 2008). Ugyanakkor a volt szocialista országok népességének egészségi állapotában is nagy különbségek vannak.

A világ országai között a magyar népesség egészségi állapota a középmezőnyben van, de az európai országok között ennél rosszabb a pozíciója, néhány mutató tekintetében pedig kétségkívül a legrosszabbak közé sorolható (Pál-Uzzoli 2008, Uzzoli 2003). A különböző kutatások egyöntetúen bizonyították, hogy nemcsak a fejlett nyugati országokhoz, hanem több posztszocialista országhoz viszonyítva is kedvezőtlenebb a hazai helyzet, aminek gyökerei az 1960-as évekig nyúlnak vissza (Józan 2008, Kopp-Skrabski 2007, Uzzoli, 2010). A visegrádi országok közül Magyarországon a legrosszabb a néhány fontosabb egészségindikátor értéke (1. táblázat).

Területi Statisztika, 2016, 56(5): 483-519; DOI: 10.15196/TS560501 


\section{Néhány fontosabb egészségmutató a visegrádi országokban}

Some important health indicators in Visegrad countries

\begin{tabular}{|c|c|c|c|c|c|}
\hline Mutató & Év & Csehország & Szlovákia & $\begin{array}{l}\text { Magyar- } \\
\text { ország }\end{array}$ & $\begin{array}{l}\text { Lengyel- } \\
\text { ország }\end{array}$ \\
\hline \multirow{4}{*}{$\begin{array}{l}\text { A férfiak születéskor } \\
\text { várható átlagos } \\
\text { élettartama, év }\end{array}$} & 1980 & $67,0^{a)}$ & - & 65,5 & 66,0 \\
\hline & 1990 & 67,6 & 66,6 & 65,1 & 66,7 \\
\hline & 2002 & 72,1 & 69,9 & 68,3 & 70,4 \\
\hline & 2013 & 75,2 & 72,9 & 72,2 & 73,0 \\
\hline \multirow{4}{*}{$\begin{array}{l}\text { A nők születéskor } \\
\text { várható átlagos } \\
\text { élettartama, év }\end{array}$} & 1980 & $74,3^{\text {a) }}$ & - & 72,7 & 74,4 \\
\hline & 1990 & 75,4 & 75,4 & 73,7 & 76,3 \\
\hline & 2002 & 78,4 & 77,6 & 76,6 & 78,8 \\
\hline & 2013 & 81,3 & 80,1 & 79,1 & 81,2 \\
\hline \multirow{4}{*}{$\begin{array}{l}\text { Ezer lakosra jutó } \\
\text { halálozás }\end{array}$} & 1981-1985 & $11,9^{\mathrm{a})}$ & - & 13,7 & 9,6 \\
\hline & 1990 & 12,5 & 10,3 & 14,0 & 10,2 \\
\hline & 2001 & 10,5 & 9,7 & 13,0 & 9,5 \\
\hline & 2013 & 10,0 & 9,5 & 12,8 & 9,9 \\
\hline \multirow{4}{*}{$\begin{array}{l}\text { Keringési rendszer } \\
\text { betegségei okozta } \\
\text { halálozások százezer } \\
\text { lakosra jutó száma }\end{array}$} & 1984-1985 & $302^{\text {a) }}$ & & 366 & 125 \\
\hline & 1990 & 699 & 520 & 737 & 534 \\
\hline & 2001-2002 & 560 & 534 & 668 & 495 \\
\hline & 2012 & 704 & 712 & 779 & 652 \\
\hline \multirow{4}{*}{$\begin{array}{l}\text { Rosszindulatú } \\
\text { daganatok okozta } \\
\text { halálozások százezer } \\
\text { lakosra jutó száma }\end{array}$} & 1985 & $233^{\mathrm{a})}$ & - & 281 & 181 \\
\hline & 1990 & 272 & 199 & 298 & 191 \\
\hline & $2001-2002$ & 281 & 220 & 330 & 215 \\
\hline & 2012 & 298 & 320 & 361 & 300 \\
\hline \multirow{4}{*}{$\begin{array}{l}\text { Öngyilkosságok, } \\
\text { önsértések százezer } \\
\text { lakosra jutó száma }\end{array}$} & 1985 & - & - & 44 & 13 \\
\hline & 1990 & 19 & 15 & 40 & 13 \\
\hline & 2002 & 15 & 13 & 28 & 14 \\
\hline & 2012 & 16 & 11 & 24 & 17 \\
\hline
\end{tabular}

a) Szlovákia adatával együtt.

Forrás: Nemzetközi statisztikai évkönyv, 1989., 2004., Egészségügyi statisztikai évkönyv, 2014.

A rendszerváltozás kezdetén mind a születéskor várható átlagos élettartam, mind a halálozások ezer lakosra jutó száma és a főbb halálokok szerinti halálozások százezer lakosra jutó száma rosszabb volt hazánkban, mint a másik három visegrádi országban. Ez lényegében annak ellenére sem változott az elmúlt negyedszázadban, hogy mindegyik visegrádi országban az 1990-es évtizedben többnyire jelentősebb, majd az ezredfordulótól egy-két mutató kivételével szerényebb mértékủ javulás következett be. 
Egyedül a százezer lakosra jutó daganatos halálozások száma emelkedett mindenhol. Ennek ellenére vitathatatlan, hogy a hazai népesség egészségi állapota több szempontból tartósan rosszabb a többi visegrádi országhoz viszonyítva, és hogy csak a tôlünk keletebbre fekvő országok mutatói kedvezőtlenebbek a mienknél (Kopp-Skrabski 2007). Például Romániában százezer lakosra 1039 szív- és érrendszeri halálozás jutott 2012-ben, míg Magyarországon 779. Oroszországban már az ezredfordulón is több (852) volt a szív- és érrendszeri betegségek okozta halálozás százezer lakosra jutó száma, mint hazánkban (668).

Nemzetközi összevetésben az is rendkívül kedvezőtlen, hogy nálunk igen magas a korai halálozás, főleg a férfiak körében. Az 1980-as évektól emelkedett az aktív középkorú (45-64 éves) férfiak halálozása, és még az ezredforduló után is magas volt az 50-64 éves férfiak idő előtti halálozása (Kopp-Skrabski 2007, Paulik 2014, Uzzoli 2010). Az EU országaihoz viszonyítva a legtöbb betegségcsoportban Magyarországon jóval magasabbak a korai halálozási arányok. A középkorú férfiak köréből a daganatos, valamint a szív- és érrendszeri betegségekből eredô halálozások szedik a legtöbb áldozatot (KSH 2010). A korai halálozás legvalószínűbben magatartási, lelki, pszichés tényezőkkel, valamint a krónikus stressz és az annak kezelésében mutatkozó különbségekkel, az eltérő megbirkózási képességekkel magyarázható, mivel a genetikai állomány, a lakosság anyagi helyzete, az egészségügyi ellátás és a hagyományos kockázati tényezôk nem romlottak jelentôs mértékben az elmúlt évtizedekben (Kopp-Skrabski 2007). Tulajdonképpen ezek a tényezők részben a magyar népesség egészségi állapotát is magyarázzák, ugyanis a természeti, a történelmi, a gazdasági, a társadalmi és a kulturális tényezők mellett vannak egyedi, sajátos okok is, amelyek gyökerei hosszú időre nyúlnak vissza (Pál-Uzzoli 2008). Következésképp annak ellenére, hogy a visegrádi országok történelmi múltja, társadalmi-gazdasági fejlődése, illetve fejlettsége és földrajzi fekvése sok hasonlóságot mutat, bizonyára valamilyen „sajátos magyar adottság” indokolja hazánk kedvezőtlen(ebb) pozícióját az egészségi állapot szempontjából, azaz népességünk rosszabb egészségi állapotát.

\section{Hazai elözmények}

A magyar népesség egészségi állapotának területi különbségeiben már a rendszerváltozás előtt is szerepet játszottak a „földrajzi helyek”, például a megyék speciális, egyedi jellemzői, de akkor még a földrajzi fekvésnek, a helyeknek nem tulajdonítottak különösebb jelentőséget (Hamilton 1995). Azt, hogy valójában milyen okok álltak az akkori egészségegyenlőtlenségek hátterében azért is nehéz kimutatni, mert a területi differenciák a megyék szintjén nem voltak élesek, amit néhány egészségmutató 1980. évi adatainak vizsgálata is tanúsít (2. táblázat).

Területi Statisztika, 2016, 56(5): 483-519; DOI: 10.15196/TS560501 


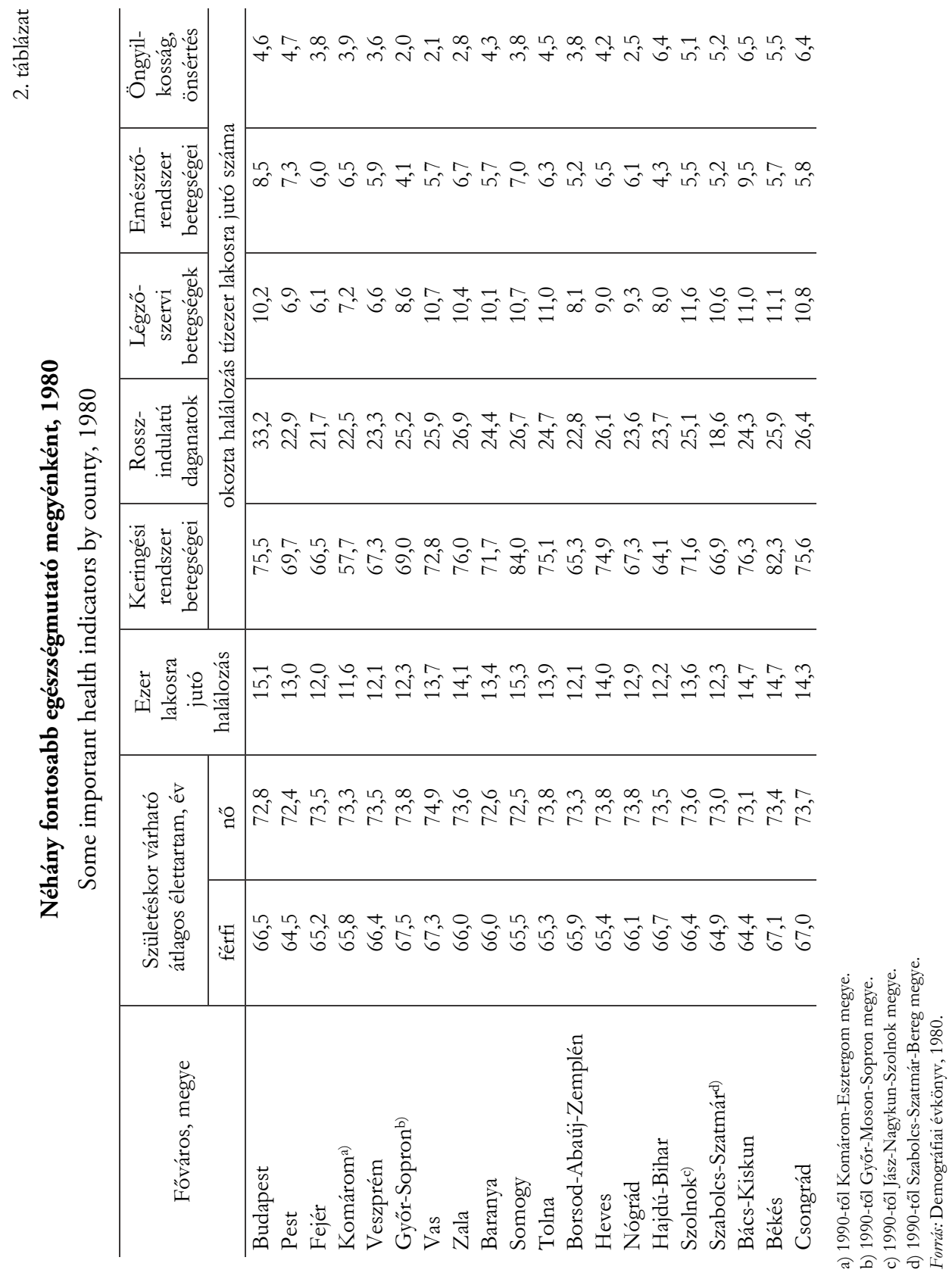


1980-ban a férfiak születéskor várható átlagos élettartama Bács-Kiskun, Pest, Szabolcs-Szatmár megyében volt a legalacsonyabb és Győr-Sopron, Vas, Békés megyében a legmagasabb. A nők életkilátásai Pest, Somogy, Baranya megyében voltak a legkedvezőtlenebbek és Vas, Győr-Sopron, Heves, Nógrád, Tolna megyében a legkedvezőbbek, habár a szélsőértékek nem mutattak éles területi differenciákat.

A halálozások ezer lakosra jutó számában 1980-ban Somogy megye, Budapest, Békés és Bács-Kiskun megye állt az élen, a sereghajtó viszont Komárom, Fejér, Borsod-Abaúj-Zemplén és Veszprém megye volt. A szív- és érrendszeri betegségek okozta halálozások centrumaként a Dél- és Délnyugat-Dunántúl, a Dél-Alföld, Pest és Heves megye jelölhetô ki, mert a tízezer lakosra jutó számuk ezekben az országrészekben érte el a legmagasabb értéket. Különösen Somogy és Békés megyében haltak meg sokan szív- és érrendszeri okok miatt. A daganatos halálozások mutatója a legtöbb megyében többnyire egyharmada volt a szív- és érrendszerinek, és a fôvváros kivételével viszonylag egyenletesebb térbeli megoszlást mutatott, amely toronymagasan kiemelkedett értékével (33). A másik végletet képező Szabolcs-Szatmár megyében rendkívül alacsony (18) volt a daganatos halálozások tízezer lakosra jutó száma.

A légzőszervi betegségek okozta halálozásokban erős a térbeli koncentráció. Az országon belül főleg a dél-alföldi és részben az észak-alföldi, valamint a dél-dunántúli megyékben magas a légzőszervi halálozás, ami csak az utóbbi megyék esetében kapcsolható össze a szocialista ipar (például bányászat) jelentősebb előfordulásával. Még koncentráltabbak a térben az emésztôszervi betegségek okozta halálozások. Az 1980-as évek elején a legtöbb ilyen halálozás Bács-Kiskun megyében, Budapesten, Pest és Somogy megyében, a legkevesebb Győr-Sopron és Hajdú-Bihar megyében fordult elő.

Az öngyilkosságok, önsértések leginkább az Alföldhöz, azon belül is elsősorban a Dél-Alföldhöz kapcsolódtak. Ez a térbeli mintázat mintegy előrevetíti, illetve bizonyos fokig meghatározza a későbbi területi megoszlást is, ami a többi mutató esetében szintén kisebb-nagyobb mértékben az 1989 utáni területi folyamatokban is megfigyelhető.

\section{Területi különbségek néhány indikátor tükrében}

\section{Születéskor várható átlagos élettartam}

Hazánkban a születéskor várható átlagos élettartam jelentôsen javult 1990 óta (bár a rendszerváltozás után átmenetileg visszaesett, főkképp a férfiaknál) és 2014-ben elérte a 75,6 évet, holott az ezredfordulón csupán 71 év volt. Ezek a mutatók az EU-28 átlagától is elmaradtak néhány évvel (például 2014-ben 5,3 évvel). A nemek életkilátásai közötti különbségek mérséklődtek az elmúlt évtizedekben. A férfiak életkilátásai 2014-ben átlagosan 7 évvel voltak rosszabbak a nőkénél, szemben a 2000. évi 8,3 évvel. A születéskor várható átlagos élettartam 1990 és 2014 között a férfiak esetében 65-rôl 72 évre, a nők esetében 74-ről 79 évre emelkedett. Ezzel egyidejüleg mindkét nem esetében a térben erősen koncentrálttá váltak a még mindig legrosszabb életkilátású területek (1. és 2 . ábra).

Területi Statisztika, 2016, 56(5): 483-519; DOI: 10.15196/TS560501 


\section{A férfiak születéskor várható átlagos élettartama megyénként}

Average life expectancy of men at birth, by county

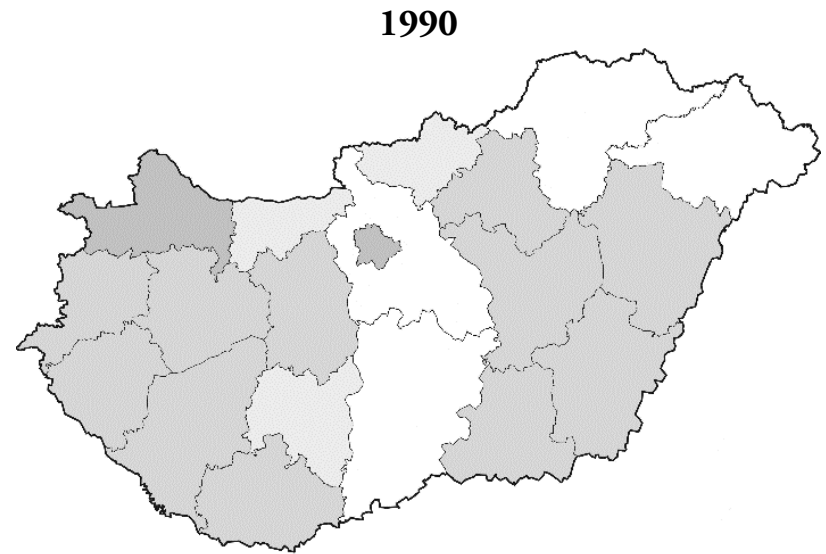

2001
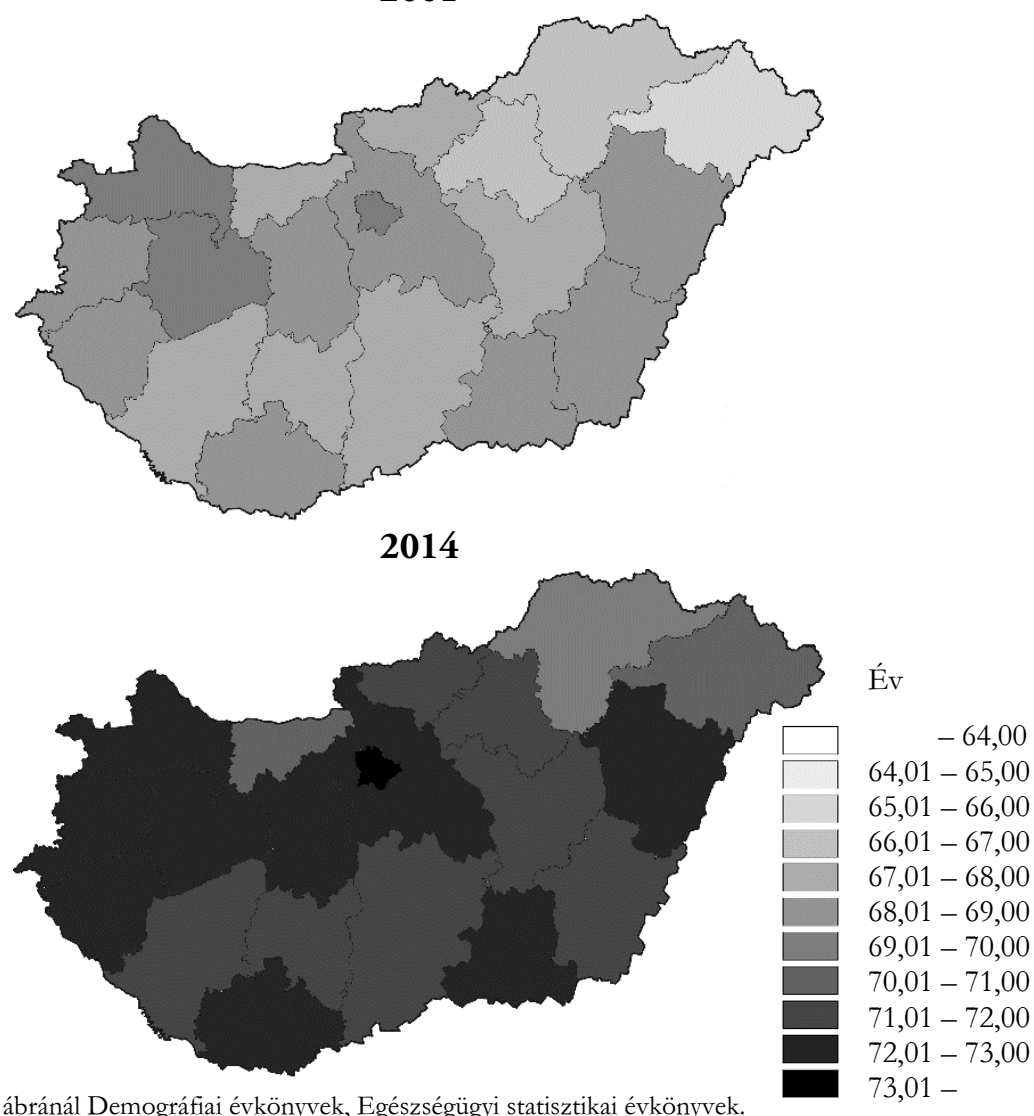

Forrás: az 1-8. ábránál Demográfiai évkönyvek, Egészségügyi statisztikai évkönyvek.

Területi Statisztika, 2016, 56(5): 483-519; DOI: 10.15196/TS560501 
A nők születéskor várható átlagos élettartama megyénként

2. ábra Average life expectancy of women at birth, by county

1990

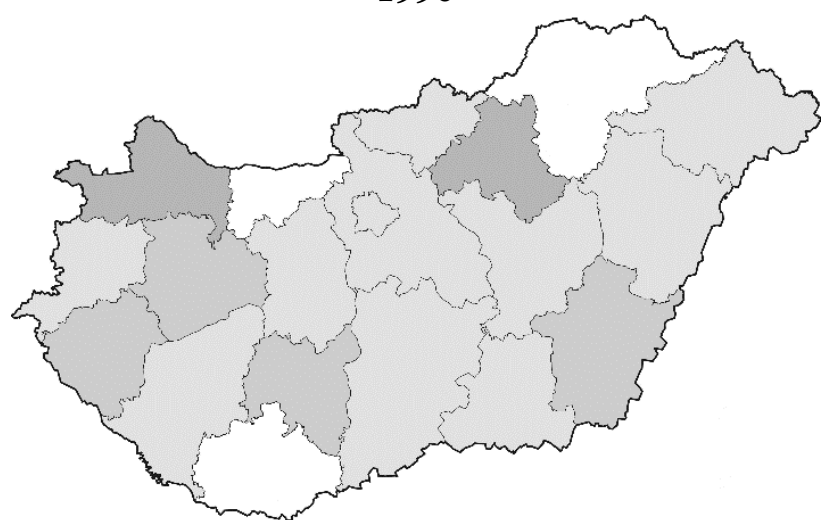

2001

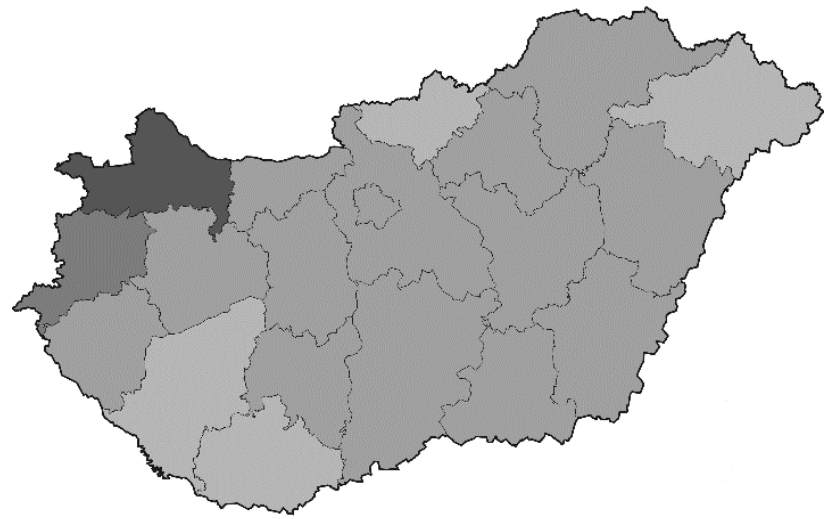

2014

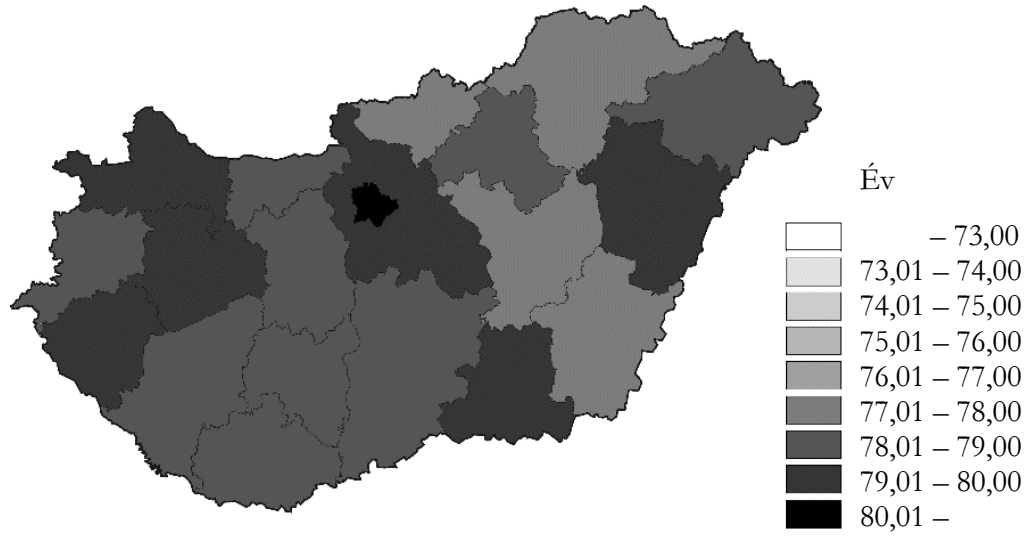

Területi Statisztika, 2016, 56(5): 483-519; DOI: 10.15196/TS560501 
Az 1990-ben született férfiak életesélye Győr-Moson-Sopron megyében volt a legnagyobb (66,8 év) és Szabolcs-Szatmár-Bereg megyében a legkisebb (63,3 év). 2014-ben viszont már Budapest (74,1 év) és Borsod-Abaúj-Zemplén megye $(69,7)$ képviselte a két szélsőértéket, különbségük meghaladta a 4,4 évet. A nők esetében a rendszerváltozás idején 2,7 év volt a különbség a szélsőértékeik között, ugyanis a várható élettartam Komárom-Esztergom megyében 72,5 és Heves megyében 75,2 év volt. Negyedszázaddal később már csak 2,4 év volt a különbség (Budapest 80 év, Békés megye 77,6 év). A nők várható élettartamában tehát mérséklődtek, ellenben a férfiak esetében nőttek a területi különbségek. A férfiak életkilátásai már hosszabb ideje Borsod-Abaúj-Zemplén, Szabolcs-Szatmár-Bereg és Komárom-Esztergom megyében a legrosszabbak. Utóbbi megye igen rossz pozíciója azért meglepó, mert a Dunántúl északi felében többnyire jobbak az egészségmutatók. A korábbiakhoz képest sikerült kilépni a legalacsonyabb várható élettartamú területek csoportjából Pest és Bács-Kiskun megyének, mert javultak az ott élő férfiak életkilátásai. A férfiak leghoszszabb életre a fóvárosban, majd Zala és Veszprém megyében számíthatnak, utóbbi megyékben tovább javultak az egyébként sem rossz életkilátások az elmúlt negyedszázadban.

A nők életkilátásaiban is - a férfiakéhoz hasonlóan - nagyfokú területi homogenizálódás figyelhető meg, mert 2014-re az ország területének jelentős hányadán 78 év feletti lett a születéskor várható átlagos élettartamuk, miközben Budapesten már meghaladta a 80 évet. 2014-re a legrosszabb életkilátású területek néhány megyére zsugorodtak, és mintegy összefüggő sávot alkotnak Nógrád és Borsod-Abaúj-Zemplén megyétől kiindulva Jász-Nagykun-Szolnokon át Békés megyéig. Ezen megyékben - Békés kivételével - már az 1990-es években is rosszabbak voltak a nők életkilátásai a többi megyéhez képest. Annak, hogy nem történt érdemi változás napjainkra sem, nagyon összetettek az okai. A budapestiek kiemelkedően jó életkilátása arra enged következtetni, hogy azt kedvezően befolyásolja a településnagyság is, mert minél népesebb egy település, annál hosszabb a várható élettartam és rövidebb a beteg időszak (Faragó 2007).

\section{Halálozások föbb halálokok szerint}

A halálozások százezer lakosra jutó számának országos értéke 1441-ről 1245-fôre esett vissza 1992 és 2014 között. A csökkenés üteme az ezredforduló után valamivel nagyobb volt, mint az 1990-es évtizedben, ami több egészséget befolyásoló tényező (például társadalmi, gazdasági környezet, iskolázottság, jövedelmi viszonyok) kedvezőbbé válásával magyarázható. Összezsugorodott a legmagasabb halálozású területek köre és kiszélesedett az alacsony halálozású területeké (3. ábra). 


\section{A halálozások százezer lakosra jutó száma megyénként}

3. ábra The number of deaths per hundred thousand inhabitants, by county
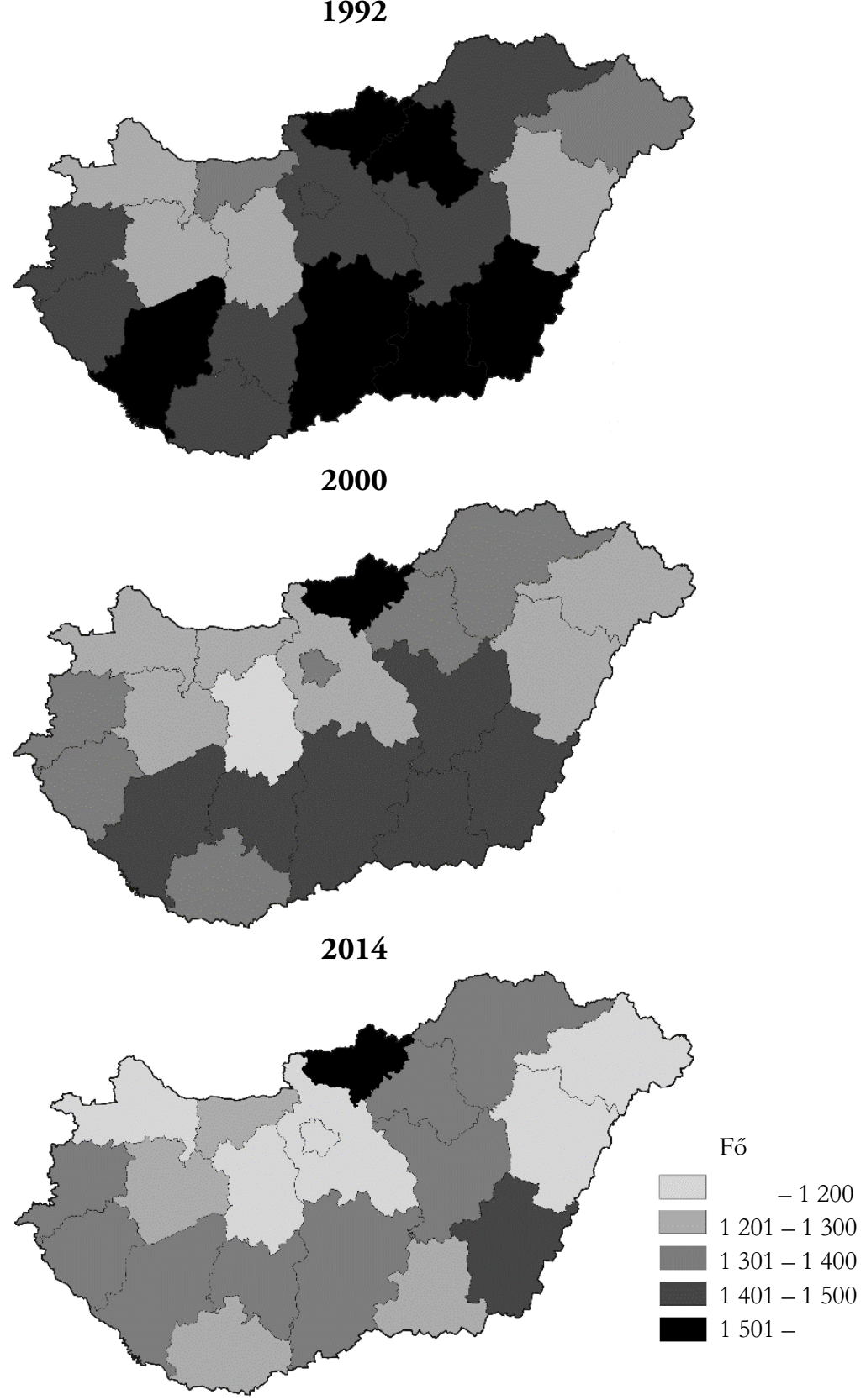

Területi Statisztika, 2016, 56(5): 483-519; DOI: 10.15196/TS560501 
A vizsgált időszakban megváltoztak a szélsőértékeket képviselő megyék, és a területi különbségek is éleződtek. A százezer lakosra jutó halálozások száma 1992-ben Békés megyében volt a legmagasabb (1569 fö) és Veszprém megyében a legalacsonyabb (1255 fő), 2014-ben viszont már Pest megyében (1081fő). Utóbbi a szuburbanizáció következtében fiatalabb korösszetételű népességgel magyarázható, ugyanis Pest megyében 2014-ben az öregedési index ${ }^{1} 194 \%$ volt, szemben a 117\%-os országos átlaggal. Ezzel egyidejúleg a legmagasabb (1504 fó) százezer lakosra jutó halálozást Nógrád megyében regisztrálták, ami a megye rendszerváltozás utáni igen kedvezőtlen társadalmi, gazdasági helyzetével magyarázható. Például a megye öregedési indexe igen magas (2014-ben 134\% volt), továbbá az egy főre jutó GDP-je és a diplomások aránya évtizedek óta a legalacsonyabbak között van az országban. Előbbi mutató 1994-ben 38, 2012-ben 42\%-kal, utóbbi 1990-ben 34, 2011-ben 40\%-kal maradt el az országos átlagtól.

A halálozások földrajzi megoszlásában jellegzetes átrendeződés nem történt, mert 2014-ben is csaknem ugyanazokban a megyékben volt magas, illetve alacsony a halálozás, mint 1992-ben. Főleg Nógrád és Békés megye lakosai vannak hosszabb ideje jóval rosszabb és Győr-Moson-Sopron, Fejér és Hajdú-Bihar megye lakosai tartósan sokkal jobb helyzetben, mint az ország más térségei. Az említett első négy megyében ez szorosan összefügghet a gazdasági, társadalmi fejlettséggel, az ötödik esetében viszont, bár az egy főre jutó GDP-t tekintve javult a pozíciója, feltételezhető, hogy más tényezőknek (például a diplomások arányának növekedése, a magas születésszám, az egészségkárosító magatartás szerényebb mértéke) is köszönhetô tartós előnye (Ambrus-Varsányi 2011). A leglényegesebb változás, hogy Közép-Magyarországon radikálisan csökkent a halálozások százezer lakosra jutó száma az elmúlt évtizedekben.

A halálozások döntő hányadát néhány vezető halálok okozza. Hazánkban éppúgy, mint a nyugati országokban a leggyakoribb halálokok a szív- és érrendszeri betegségek, amelyek az összes halálozás csaknem felét teszik ki. Kedvezőtlen, hogy jelentős hányadukat (2010-ben 15\%-ukat) a korai (65 éves kornál korábbi) halálozások adták a standardizált halálozási arányszámok alapján (KSH 2010). A szív- és érrendszeri betegségek okozta halálozásoknak az öröklött tényezők mellett számos egyéb oka (helytelen táplálkozás, mozgásszegény életmód, egészségkárositó szokások stb.) lehet (Kiss 2005).

Bár a keringési rendszer betegségei okozta halálozások százezer lakosra jutó száma 1992 és 2014 között 739-ről 636-ra csökkent, a regionális különbségek növekedtek és a földrajzi megoszlásuk is módosult. Ezek a halálozások (kiváltképp az ezredfordulóig) nagyfokú hasonlóságot mutattak az összes halálozás százezer lakosra jutó számának területi megoszlásával, ami elsődlegesen annak a következménye, hogy a halálozások többségét a keringési betegségekből származók teszik ki, ezért a befolyásuk a térben is tükröződik (4. ábra).

\footnotetext{
${ }^{1}$ Az idős népesség (65- éves) a gyermeknépesség (0-14 éves) százalékában.
}

Területi Statisztika, 2016, 56(5): 483-519; DOI: 10.15196/TS560501 
A keringési rendszer betegségei okozta halálozások százezer lakosra jutó száma megyénként

The number of deaths per hundred thousand inhabitants caused by the diseases of the circulatory system, by county
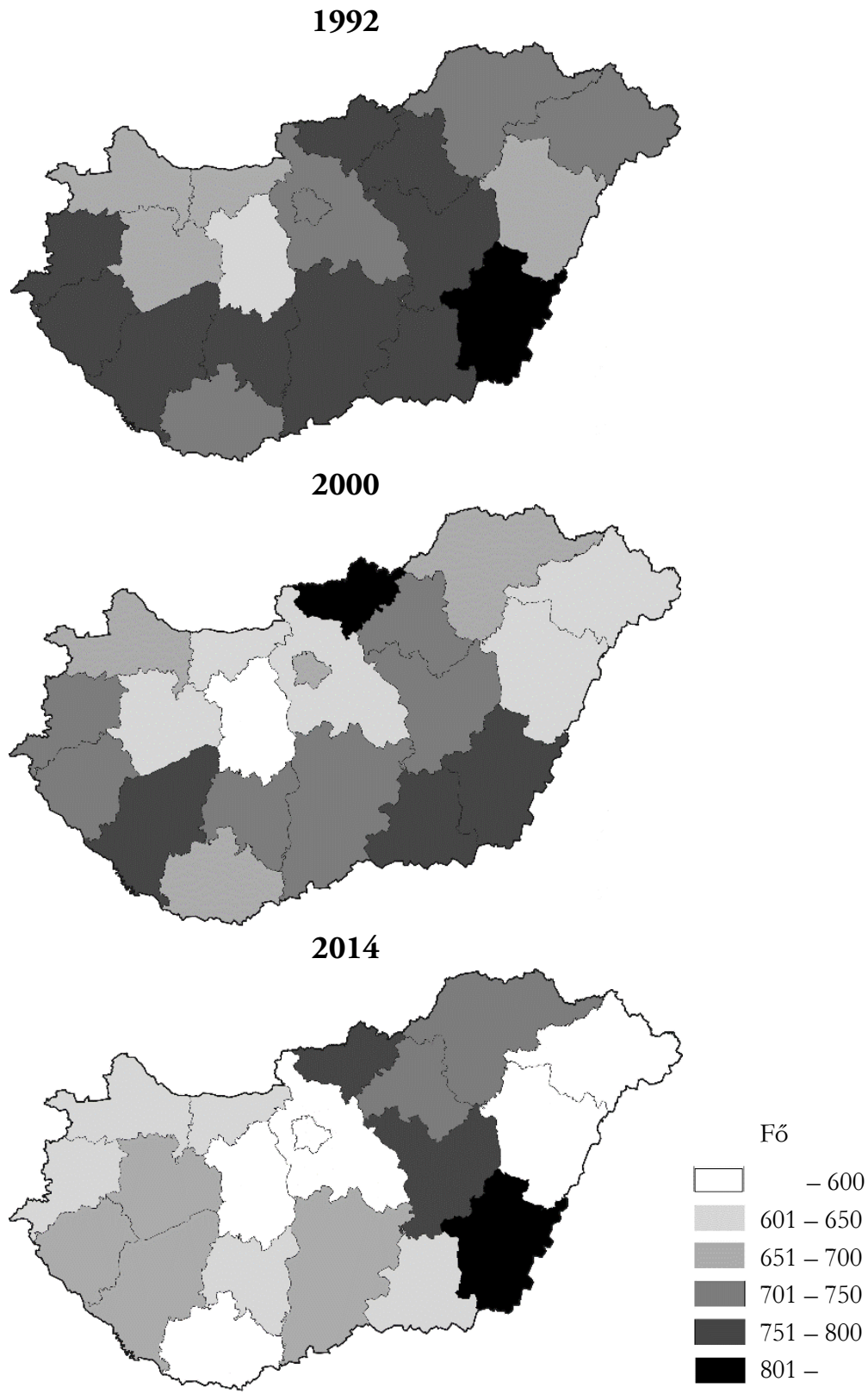

Területi Statisztika, 2016, 56(5): 483-519; DOI: 10.15196/TS560501 
1992-ben a Nógrád megyétől Heves és Jász-Nagykun-Szolnok megyén át Békés megyéig, északi-délkeleti és a Békés megyétől Csongrád, Bács-Kiskun, Tolna, Somogy és Zala megyén át Vas megyéig, nyugati-délkeleti irányban húzódó sávban volt a legmagasabb a szív- és érrendszeri halálozások százezer lakosra jutó száma. 2014-ben az előbbi „övezetek” közül az északi-délkeleti sávban továbbra is magas ez a halálozási mutató, sőt Jász-Nagykun-Szolnok megyében emelkedett is, és csatlakozott ehhez az „övezethez” Borsod-Abaúj-Zemplén megye is. Ezzel szemben a nyugati-délkeleti irányú „övezetben” mérséklődött a szív- és érrendszeri halálozások százezer lakosra jutó száma. A korábban összefüggő sávban ma már csak „foltokban” magasabb ez a halálozási mutató. Mindvégig kimagasló volt a keringésrendszeri halálozások százezer lakosra jutó száma Békés és Nógrád megyében, ami az 1989 utáni kedvezőtlen társadalmi, gazdasági változásokkal, a romló életkörülményekkel, az elszegényedéssel, a magas munkanélküliséggel stb. indokolható a leginkább. Ezt az említett két megye néhány fontosabb egészségi állapotot befolyásoló mutatóinak (például a diplomások aránya, munkanélküliség, egy főre jutó bruttó átlagkereset, egy főre jutó GDP) 1992 és 2014 közötti időszakra vonatkozó vizsgálata támasztja alá. Ugyanakkor Fejér megyéhez, ahol az elmúlt évtizedekben végig alacsony volt a keringési betegségek okozta halálozások százezer lakosra jutó száma, 2014-re más területi egységek (Budapest, Pest, Hajdú-Bihar, Szabolcs-Szatmár-Bereg és Baranya megye) is társultak. Így a halálozási szempontból kedvező területek súlypontja az ország központi részére és az Észak-Alföldre helyeződött át, aminek hátterében nagyon sok tényező (például a javuló életkörülmények, az egészségtudatosabb életmód és táplálkozás, az egészségügyi ellátórendszer javulása) áll, de az egyes területi egységek esetében különböző mértékben.

A halálozások több mint negyedét teszik ki a daganatos betegségekből eredők, amelyek a második helyen állnak a halálokok között hazánkban és az Európai Unióban egyaránt (Kiss 2005, Uzzoli 2003). Az Európai Unióban ma is a legrosszabbak között vagyunk ezzel a mutatónkkal. Ráadásul Magyarországon a korai halálozások jelentős hányadát, 2010-ben több mint 54\%-át a rosszindulatú daganatok okozták a standardizált halálozási arányszámok alapján, az EU-ban „csak” 42,5\%-át (KSH 2010). A százezer lakosra jutó daganatos halálozások száma az 1990-es években nőtt, az ezredfordulótól viszont magas szinten stagnál. 1992-ben 317, 2014-ben pedig 332 volt az értéke. Ezzel párhuzamosan a területi különbségek nivellálódtak, de negatív irányba, mert több megyében lett magasabb az indikátor értéke (5. ábra). 


\section{A rosszindulatú daganatok okozta halálozások százezer lakosra jutó száma megyénként}

The number of deaths per hundred thousand inhabitants caused by neoplasms, by county
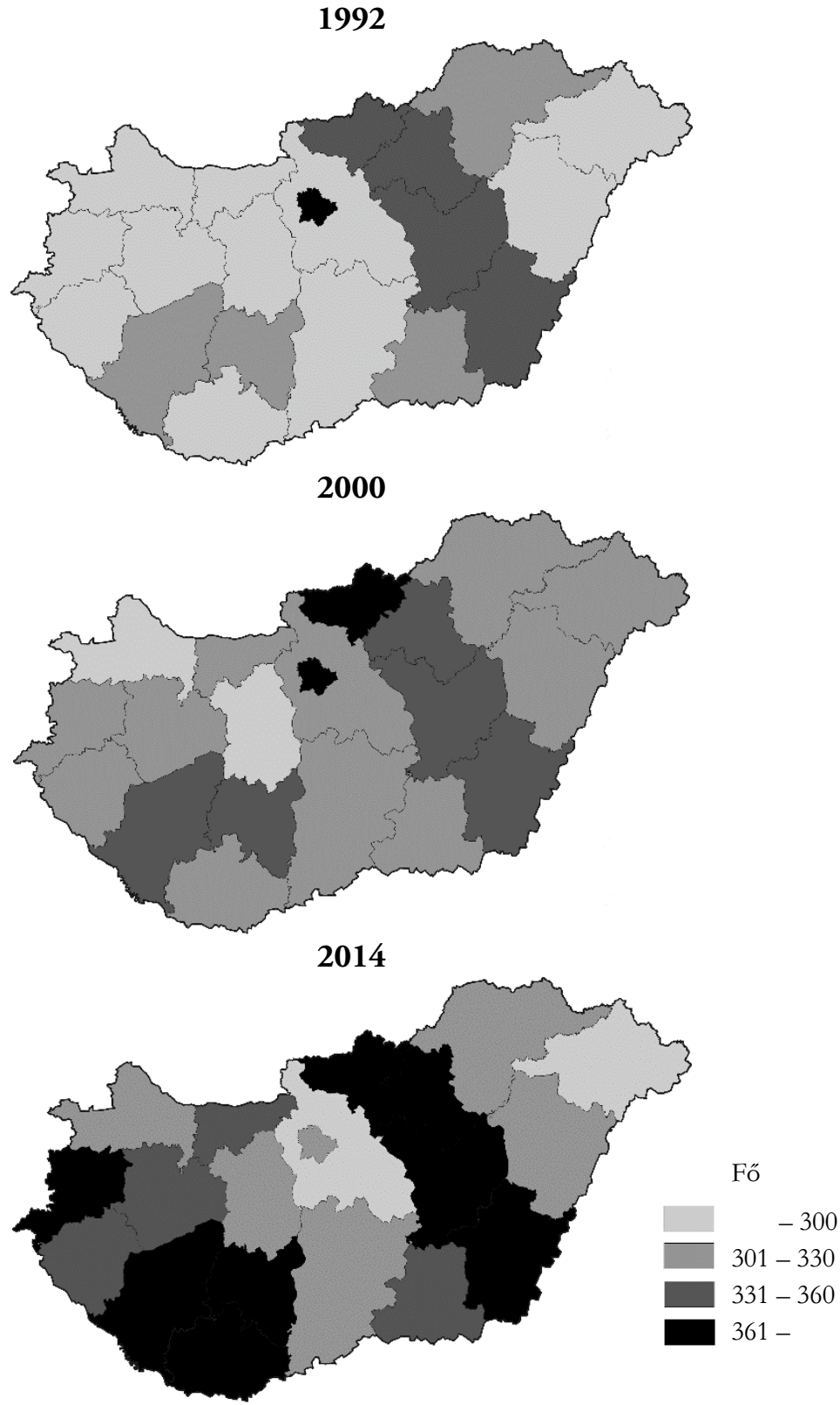

Területi Statisztika, 2016, 56(5): 483-519; DOI: 10.15196/TS560501 
A daganatok okozta halálozások százezer lakosra jutó száma 1992-ben Budapesten volt a legmagasabb (379), amit Heves (353), Békés (344), Jász-Nagykun-Szolnok (344) és Nógrád megye (332) követett, mintegy összefüggő sávot alkotva északról délkelet felé. A legkevesebben viszont Veszprém (255), Szabolcs-Szatmár-Bereg (260) és Fejér megyében (271) haltak meg valamilyen tumor miatt. Nem változott 2014-re a Nógrád megyétől Békés megyéig terjedő „sávnak” a daganatos halálozásban elfoglalt kiemelkedő helye. A korábban is kedvezőtlen mutatóval rendelkező megyékben tovább emelkedett a daganatos halálozás, miközben az a térben is jobban kiterjedt. Az ezredfordulótól újabb övezetek alakultak ki a Dunántúlon Komárom-Esztergom megyétől Zala megye irányába, illetve Vas megyétől Baranya megyéig, az országhatár mentén. Arra vonatkozóan, hogy ennek mi lehet az oka, csak feltételezésekre támaszkodhatunk. Nevezetesen, hogy például a megyék gazdasági pozíciója kedvezőtlenül változott 1989 után, a Dél-Dunántúl az egyik nagy vesztese volt az ipari átalakulásnak, és hogy magas az erős dohányosok aránya a régióban, valamint nem előnyösek a településviszonyok, ami az egészségügyi ellátás igénybevételét is megnehezíti, továbbá az egészségkultúra alacsony szintje (Ambrus-Varsányi 2011, Kiss 2010, Pál 2013).

Annak ellenére, hogy a rendszerváltozás óta Budapesten folyamatosan csökken a százezer lakosra jutó daganatos halálozás, mégis Szabolcs-Szatmár-Bereg megyében jutott a legkevesebb ilyen halálozás százezer lakosra az elmúlt évtizedekben és 2014ben is. Éppen ezért érdemes lenne alaposabban tanulmányozni, hogy mi lehet a megye „titka”, mert az támpont lehetne más megyék számára is a daganat okozta halálozások mérsékléséhez. Mivel ez a megye nem tartozik és sohasem tartozott a legfejlettebb térségekhez, és mert a társadalmi-gazdasági szempontból fejlettebb országrészekben szintén emelkedett a daganatos halálozások száma a vizsgált időszakban, ezért megállapíthatjuk, hogy a társadalmi-gazdasági fejlettség önmagában nem elégséges, más tényezők is szükségesek a daganatos halálozások számának mérsékléséhez. Tovább árnyalhatja a daganatos halálozások földrajzi megoszlásának megítélését az a tény, hogy a különböző daganatfajták szerepe és térbeli mintázata többé-kevésbé eltérő (Kiss et al. 2003).

A légzőrendszeri betegségekre visszavezethető halálozások az összes halálozás 5,5\%-át tették ki 2014-ben, ami nem számottevô a vezetô halálokok okozta halálozások részesedésével összevetve. Pesszimizmusra ad okot azonban, hogy napjainkban is növekszik a százezer lakosra jutó számuk (1992 és 2014 között 67-ről 70-re). Továbbá az is kedvezőtlen, hogy a standardizált halálozási mutatók szerint hazánkban a korai halálozások több mint egyharmadáért (2010-ben 36\%-áért) és az EU-27-ben átlagosan körülbelül egyötödéért a légzőrendszeri betegségek felelősek (KSH 2010).

A környezetszennyezés fokozódásának egyik mutatójaként a levegő szennyezettsége is nő, ami nemcsak a légzőszervi (például allergiás) megbetegedések szaporodását eredményezheti a jövőben, hanem végső soron a szervezet egészének a különböző megbetegedéseit is okozhatja (Antal-Péter 2016). A fejlett, a közepesen fejlett és a fejlődő országok csoportjainak vizsgálata azt mutatta, hogy a társadalmi-gazdasági fejlettségi lejtő nagymértékben meghatározza a légzőrendszer betegségeinek alakulását, és a világ szegényebb felén a tbc, a gazdagabb részén a légzőszervi rák pusztít inkább (KSH 2009).

Területi Statisztika, 2016, 56(5): 483-519; DOI: 10.15196/TS560501 
A légzőrendszeri betegségekből eredő halálozások százezer lakosra jutó száma megyénként

The number of deaths per hundred thousand inhabitants caused by the diseases of the respiratory system, by county
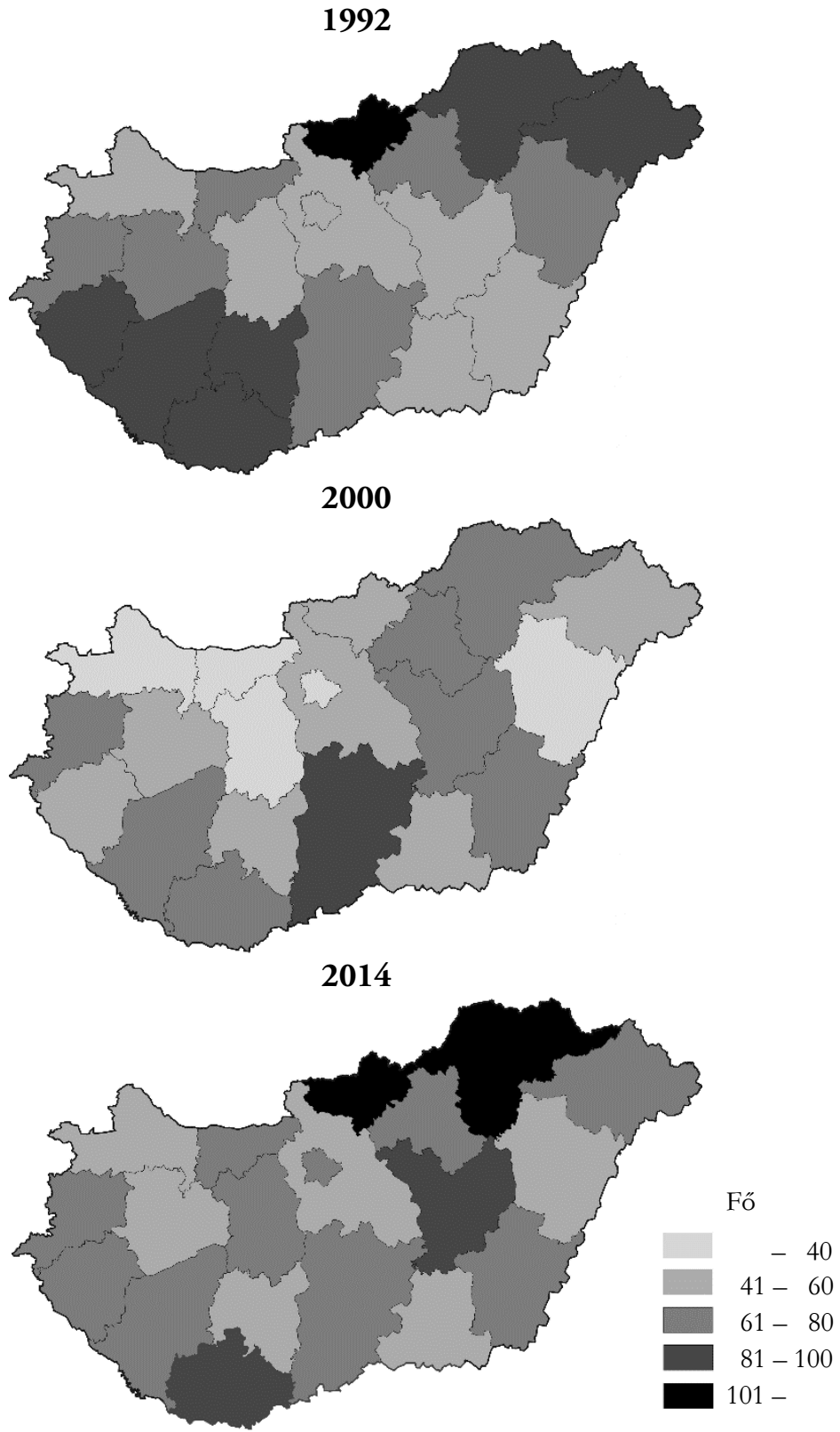

Területi Statisztika, 2016, 56(5): 483-519; DOI: 10.15196/TS560501 
Hazánkban százezer lakosra a legtöbb légzőszervi betegségekből eredő haláleset Nógrádban (120), Borsod-Abaúj-Zemplén (107), Jász-Nagykun-Szolnok (98) megyében jutott 2014-ben és a legkevesebb Győr-Moson-Sopron (44), Hajdú-Bihar (49), Pest (55) megyében (6. ábra).

A légzőrendszeri halálozás stabilan az ország északi-északkeleti részében és a Dél-, Délnyugat-Dunántúlon a leggyakoribb, ami összefügghet az ottani dohányzási szokásokkal is. A rendszeresen dohányzók aránya a Dél-Dunántúlon (34\%) és ÉszakMagyarországon (29\%) volt a legmagasabb, Közép- és Nyugat-Dunántúlon (24\%), továbbá az Alföldön (25\%) a legalacsonyabb. Általában a diplomások körében magasabb a nemdohányzók aránya és az alacsonyabb iskolai végzettségúek körében az erős dohányosoké (Ambrus-Varsányi 2011). A légzőszervi halálozás tartós térstruktúrája valójában annyiban változott napjainkra, hogy a központi régióban és az azzal határos megyékben emelkedett.

A területi különbségek ugyan alig erősödtek, ám határozottan nőtt a magasabb légzőszervi halálozással rendelkező területek térbeli kiterjedése. 1992 és 2014 között a fővvárosban, valamint Borsod-Abaúj-Zemplén és Jász-Nagykun-Szolnok megyében intenzívebben, Vas, Fejér, Békés és Baranya megyében kisebb mértékben emelkedett a légzőrendszeri betegségek okozta halálozások százezer lakosra jutó száma. A megyék közül a legnagyobb mértékű növekedés Jász-Nagykun-Szolnok megyében (52ről 98-ra) ment végbe a vizsgált időszakban, s ezzel a harmadik helyre került a megyék rangsorában, Nógrád és Borsod-Abaúj-Zemplén megye után.

Habár az emésztőrendszer betegségei egyre kevesebb halálozást okoznak idehaza, az mindenképp kiemelendő, hogy a standardizált halálozási arányszámok alapján ezeknek a halálozásoknak a döntő hányada (2010-ben 70\%-a) korai halálozás, szemben az EU-val, ahol kevesebb, mint fele (2010-ben 49\%-a) (KSH 2010). Az emésztőszervi halálozások csökkenő száma - többek között - az egyre tudatosabb táplálkozással és a fogyasztási szokások változásával magyarázható. De hozzájárulhatott ehhez az is, hogy az áremelkedések miatt az elfogyasztott élelmiszerek mennyisége szintén visszaesett és a minősége is sokszor kedvezőtlenül változott. Ez különösen jellemző a rendszerváltozás utáni évekre és napjainkban a rosszabb anyagi helyzetben levő társadalmi csoportokra (Földi 2007, Kozák 2009). Az elhízottak aránya a nyugati országrészben az átlagosnál alacsonyabb, a keleti országrészben magasabb. Ehhez hasonló térbeli megoszlást regisztráltak a zöldség- és gyümölcsfogyasztás gyakoriságában is, mivel a Dunántúlon gyakrabban fogyaszt a felnőtt lakosság gyümölcsöt, zöldséget, mint az ország más térségeiben élők. Az egészségtudatos táplálkozásra a legnagyobb figyelmet Közép-Magyarországon és Észak-Dunántúlon fordították (AmbrusVarsányi 2011).

Az emésztőrendszer betegségeiből származó halálozások országos átlaga csaknem 40\%-kal lett kisebb a vizsgált időszakban, miközben a korábban az ország középső részére, a Duna vonalára és Észak-Magyarországra való erős térbeli koncentrálódását egy egyenletesebb földrajzi megoszlás váltotta fel (7. ábra).

Területi Statisztika, 2016, 56(5): 483-519; DOI: 10.15196/TS560501 


\section{Az emésztőrendszer betegségei okozta halálozások}

\section{százezer lakosra jutó száma megyénként}

The number of deaths per hundred thousand inhabitants caused

by the diseases of the digestive system, by county
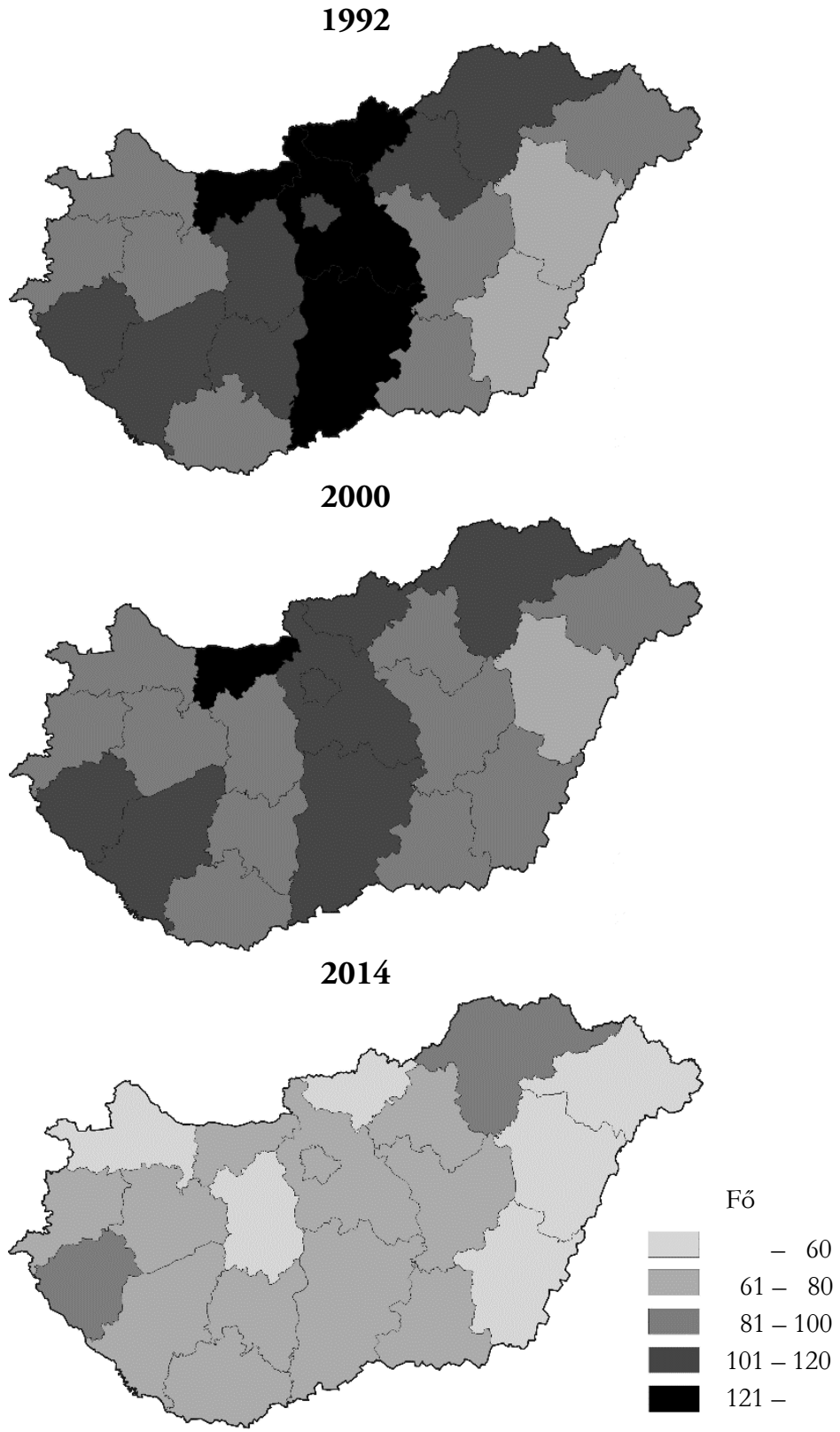

Területi Statisztika, 2016, 56(5): 483-519; DOI: 10.15196/TS560501 
Az emésztőrendszeri betegségekből származó halálozások területi különbségei gyengültek a rendszerváltozás óta. 1992-ben Pest (134), Komárom-Esztergom (131), Bács-Kiskun (129) és Nógrád (128) megye állt az élen az emésztôszervi halálozások százezer lakosra jutó számában. 2014-re Zala (82) és Borsod-Abaúj-Zemplén (81) megye vette át a vezetést, és Komárom-Esztergom (74) megye a harmadik helyre szorult vissza, ami azt jelentette, hogy továbbra is megórizte helyét az élbolyban. Ugyanakkor az ilyen jellegú halálozások száma a Tiszántúl és - Komárom-Esztergom kivételével a Dunántúl északi részén, valamint Észak-Magyarország nyugati felében volt a legalacsonyabb 2014-ben. Az összes területi egység közül Békés és Hajdú-Bihar megyében bizonyult tartósan alacsonynak az emésztőszervi halálozások százezer lakosra jutó száma 1992 és 2014 között. Az is kedvező, hogy az ezredforduló óta a szerény mértékú javulás ellenére bővült azon területi egységek köre Győr-Moson-Sopron, Fejér, Nógrád és Szabolcs-Szatmár-Bereg megyével, ahol napjainkban a legalacsonyabb az emésztőszervi halálozás. Eltolódás következett be tehát az alacsony halálozású területek javára, mellyel egyidejűleg a magas emésztőszervi halálozások erősen koncentrálttá váltak az országon belül. Ez pedig szintén arra hívja fel a figyelmet, hogy érdemes lenne ezeket a területeket részletesebben vizsgálni a jövőben, az okok feltárása érdekében.

Fontos megjegyezni, hogy az emésztőszervi halálozások számottevő részét a máj betegségei, mindenekfelett a májzsugor képezi, ami alapvetôen a túlzott alkoholfogyasztás következménye. Habár az elmúlt évtizedekben alig változott az egy főre jutó alkoholfogyasztás hazánkban, már nem tartozunk az európai „élvonalhoz”. 1991-ben 10,7, 2000-ben 11,2 és 2010-ben 10,8 liter elfogyasztott alkohol jutott egy före hazánkban. Ez utóbbival a 11. helyen álltunk az EU-tagállamok között, 2,1 literrel elmaradva el az élen álló Litvániától (European Parliament 2010).

Az emésztőszervi halálozások csökkenéséhez valószínúleg az is hozzájárult még Magyarországon, hogy az alkoholisták becsült száma kevesebb mint felére (390 ezerre) esett vissza 2000 és 2013 között. Az alkoholfogyasztási szokásokban szintén markáns regionális különbségek vannak. Egy néhány éve készült felmérés szerint az alkoholfogyasztásban a gazdaságilag fejlettebb országrészek, Dunántúl és KözépMagyarország lakossága járt az élen. A mértékletes alkoholfogyasztók aránya NyugatDunántúlon volt a legmagasabb (19\%), a nagyívóké Dél-Dunántúlon (6,2\%). Ezzel szemben a mértékletes alkoholfogyasztók, illetve a nagyivók legalacsonyabb arányát Észak-Alföldön (12,5, illetve 3\%) és Észak-Magyarországon (13,3, illetve 3\%) mérték. Ugyancsak ezekben a régiókban a legmagasabb az alkoholt egyáltalán nem fogyasztók aránya is (Ambrus-Varsányi 2011).

\section{Mentális egészség}

A lakosság egészségi állapotát nemcsak a fizikai, a testi egészség határozza meg, hanem a lelki egészség is. Ez utóbbi ugyanis közvetve befolyásolja más betegségek kialakulását vagy megszúnését, ezért egyáltalán nem mindegy, hogy mi jellemzi ebből a

Területi Statisztika, 2016, 56(5): 483-519; DOI: 10.15196/TS560501 
szempontból a népességet. Kutatások igazolták, hogy ahol jobb a lakosság kedélyállapota, ott alacsonyabb a krónikus szorongásban, depresszióban vagy egyéb pszichés betegségben szenvedők aránya (Ambrus-Varsányi 2011, Kopp 2003).

Az öngyilkosságok mint a mentális egészség minőségének indikátora a halálozások sajátos csoportját alkotják (Dzúrová-Dragomirecká 1997). Az öngyilkosság és önsértés következtében történő halálozások százezer lakosra jutó száma még mindig magasabb hazánkban (2014-ben 20), mint több európai országban (például Franciaországban és Lengyelországban egyaránt 17, Szlovákiában és Németországban egyaránt 12), habár folyamatos a javulás az 1980-as évek végétől. Ennek ellenére még mindig a nagy szuicid hajlammal rendelkezó országok közé tartozunk (Bálint 2008). Azt, hogy mi vezet ténylegesen öngyilkossághoz és önsértéshez, nehéz pontosan meghatározni, mivel az általában több ok (létbizonytalanság, megoldhatatlannak tûnő családi és személyes problémák, munkanélküliség, elszegényedés, reményvesztés stb.) együttesével magyarázható. Belejátszhat még a lakosság mentális egészségének milyensége, a lokális kultúra, a tradíciók stb. is (Bálint 2008).

Magyarországon 1990 és 2014 között 4133-ról 1927-re esett vissza az öngyilkosságok éves száma, ami az összes halálozásból való részesedés 2,8\%-ról 1,7\%-ra csökkenésével járt együtt. Ám e nagyarányú javulás többféle (például társadalmi-politikai tényezők, pszichiátriai ellátás jobbá válása, toxikus anyagokhoz való hozzáférés megnehezítése) magyarázata ellenére sem tisztázottak még a tényleges okok (Bálint 2008). Nemzetközi kutatások szerint az öngyilkosságok országok közötti különbsége 57\%-ban hat tényező (a válások és a munkanélküliség alacsony aránya, a bizalom és a hívők magas aránya, civil szervezetekben való gyakori részvétel, kormányzat jobb észlelt minősége) eredője (Kopp-Martos 2011). Ezek akár a megyék közötti differenciákat is indokolhatják bizonyos mértékig. Az is sok mindent elárul a magyar lakosság mentális állapotáról, hogy 2009-ben a világ 120 országa közül Magyarország volt a harmadik két afrikai ország után, ahol a legtöbben (34\%) érezték úgy, hogy életminőségük rossz és abban nem is várható javulás öt éven belül (Kopp-Martos 2011).

Az öngyilkosságok sajátos és tartós térbeli mintázata hosszú múltra tekint vissza, aminek okait szintén nem sikerült még megfejteni (Bálint 2008). Az alföldi megyék, különösen a dél-alföldiek tradicionálisan az ország leginkább öngyilkosságra és önsértésre hajlamos területei, ami a tanyasi életforma térségbeli elterjedtségével is összefüggésbe hozható. 1992-től az öngyilkosságok területi megoszlása sokat változott, és 2014-ig az öngyilkosságra és önsértésre legnagyobb arányban hajlamos terület a Tiszántúlra és Bács-Kiskun megyére szorult vissza (8. ábra).

Területi Statisztika, 2016, 56(5): 483-519; DOI: 10.15196/TS560501 
Az öngyilkosságok, önsértések százezer lakosra jutó száma megyénként The number of deaths per hundred thousand inhabitants caused by suicide and self-injury, by county
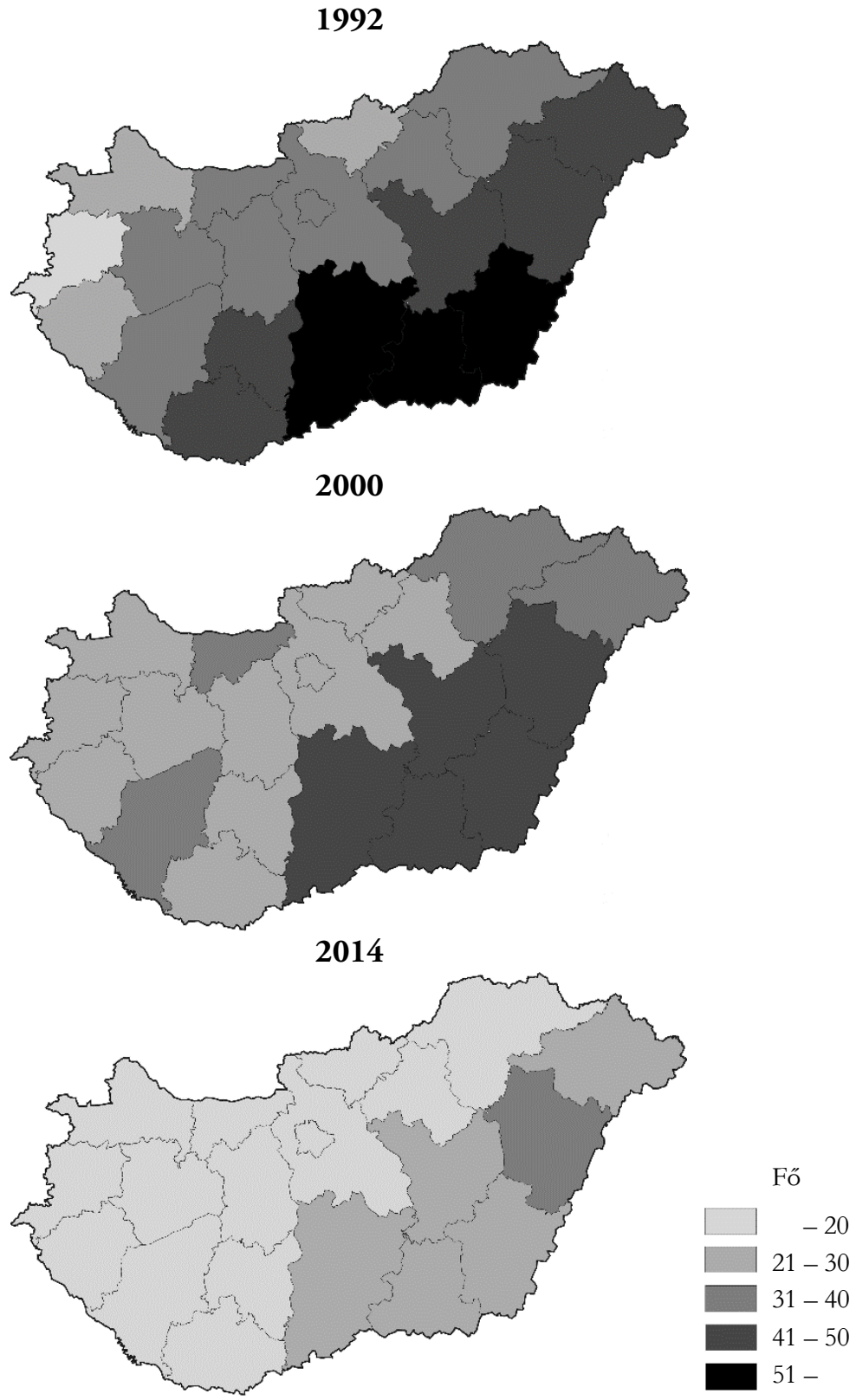

Területi Statisztika, 2016, 56(5): 483-519; DOI: 10.15196/TS560501 
Az 1990-es évek elején százezer lakosra a legkevesebb öngyilkosság Vas megyében (19) és a legtöbb Csongrád megyében (54) jutott. 2014-ben a szélsőértékeket Vas (11) és Hajdú-Bihar (31) megye képviselte, arányszámaik pozitív területi kiegyenlítődésre utalnak. Az elmúlt évtizedekben az öngyilkosságok koncentráltabbá váltak a térben. A súlypont áthelyeződött Hajdú-Bihar és Békés megye területére. Ezeken az ún. „magterületen” kívül még a Tiszántúl más megyéiben és Bács-Kiskun megyében napjainkban is magas az öngyilkosságok száma, a legkevesebbet Közép-Magyarországon és a Nyugat-Dunántúlon jegyezték. Ez mindenekelőtt a kedvezőbb társadalmi-gazdasági környezetből és a jobb mentális közérzetből fakadhat, ami szoros kapcsolatot mutat egy korábbi felmérés tapasztalataival, miszerint az említett térségekben élók között több a boldog és kevesebb a krónikus szorongásban, depresszióban vagy más pszichés betegségben szenvedő, mint az ország más részében (Ambrus-Varsányi 2011). De egyéb okoknak (például más kulturális minták, történelmi múlt, hagyományok) is tulajdonítható a kevesebb öngyilkosság ezekben az országrészekben.

A 21. században a mentális problémák egyre nagyobb teret kapnak az egészségügyben. Hazánkban is gyarapodik a mentális és a magatartási betegségekkel, illetve zavarokkal küszködők száma. A Közép-Tiszavidék elmaradott térségében már a rendszerváltozás idején arról számoltak be a háziorvosok, hogy egyre több a pszichoszomatikus tünet a rendeléseken megjelentek körében (Kiss 1993). Kiugróan magas a pszichiátriai kórképek előfordulása húsz évvel később egy másik hátrányos helyzetű térségben (az Ormánságban) is (Pál 2013). A pszichés problémák közül is kiemelkedik a depresszió. Századunk a depresszió korszakának is tekinthető (Gidai 2010). 1988ban a népesség 7,5, 1995-ben már 14\%-a panaszkodott közepes vagy súlyos depreszszióról. 2006-ra pedig tovább emelkedett az arányuk, ami az alapján is feltételezhető, hogy a súlyos depressziós tünetegyüttessel rendelkezők részesedése meghaladta a 11\%-ot (Kopp 2003, Kopp-Martos 2011). Talán ezért sem véletlen, hogy a pszichiátriai gondozottak tízezer lakosra jutó száma gyarapodott az elmúlt évtizedekben, néhol (Hajdú-Bihar, Jász-Nagykun-Szolnok, Pest megye) igen erőteljesen (9. ábra).

Területi Statisztika, 2016, 56(5): 483-519; DOI: 10.15196/TS560501 
Kiss Éva

\section{A pszichiátriai gondozókban nyilvántartottak} tízezer lakosra jutó száma megyénként

The number of registered patients in psychiatric care per ten thousand inhabitants, by county

1992

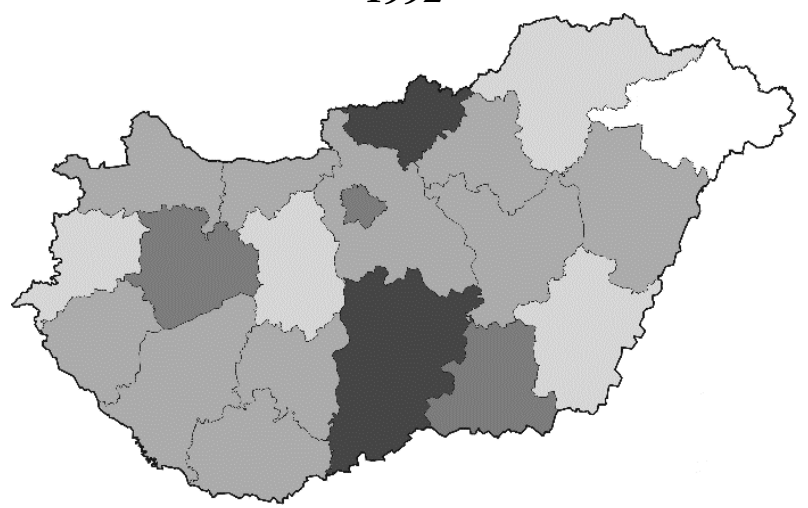

2000

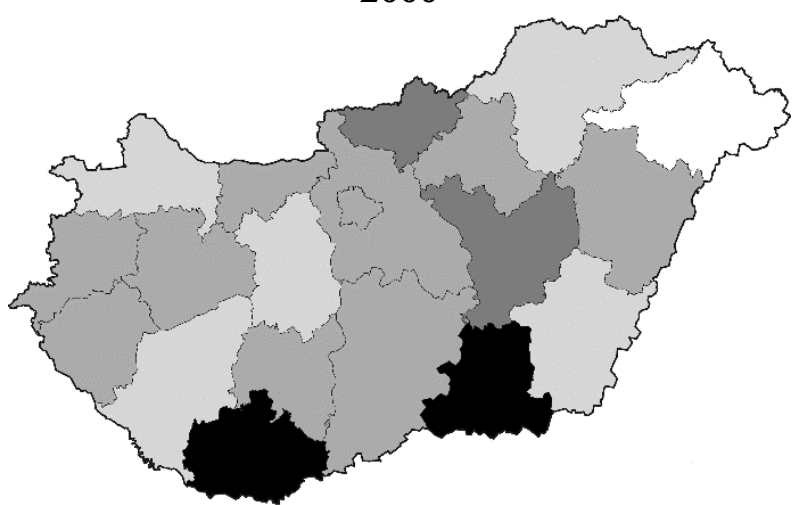

2014

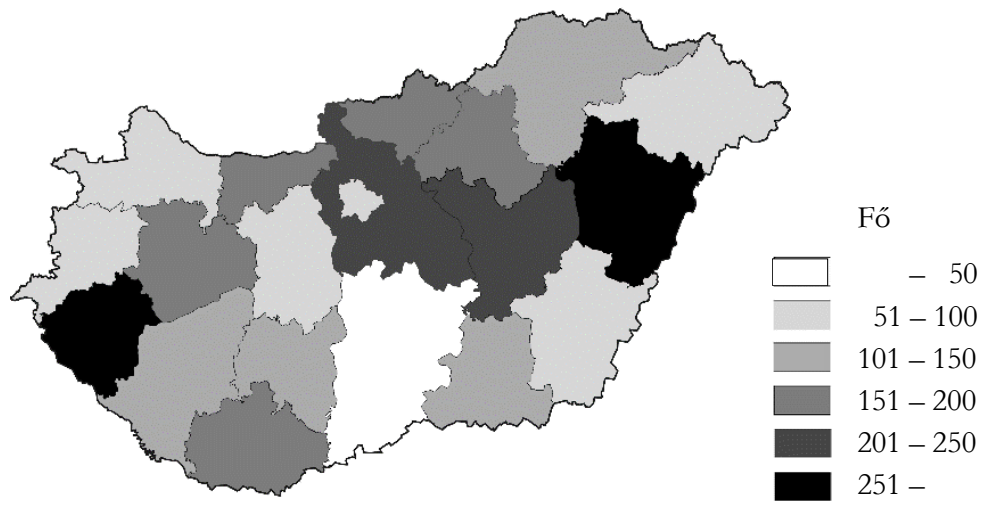

Forrás: Területi statisztikai évkönyvek, Demográfiai évkönyvek.

Területi Statisztika, 2016, 56(5): 483-519; DOI: 10.15196/TS560501 
A lakosság mentális egészségi állapota tovább jellemezhető a pszichiátriai gondozottak számának vizsgálatával. 1992-ben tízezer lakosra vetítve a legkevesebb gondozottat Szabolcs-Szatmár-Bereg megyében (150 fö) tartották nyilván, majd Fejér és Borsod-Abaúj-Zemplén megye következett. 2014-re azonban Bács-Kiskun és GyőrMoson-Sopron megye került az élre, ami nagymértékú térbeli átrendeződést jelez, miközben Fejér megye megőrizte kedvező pozícióját. Amíg 1992-ben Bács-Kiskun (212) és Nógrád (211) megyében volt a legmagasabb a gondozottak tízezer lakosra jutó száma, addig 2014-ben már Zala (365) és Hajdú-Bihar (312) megyében. Ezzel egyidejúleg Pest, Hajdú-Bihar és Jász-Nagykun-Szolnok megye pozíciója sokat romlott, csakúgy, mint Zala megyéé. Lényegében két új övezet körvonalai rajzolódnak ki: az egyiké - a Komárom-Esztergomtól Veszprém megyén át Zala megyéig húzódó sávé - valamelyest halványabban, a másiké - Pest megyétől Jász-Nagykun-Szolnokon át Hajdú-Bihar megyéig terjedó sávé - határozottabban, mert itt sokkal több a pszichiátriai gondozottak tízezer lakosra jutó száma. A rendszerváltozás óta tehát a regionális különbségek mélyültek, és a mentális betegségek földrajzi kiterjedése növekedett. Ez azzal is magyarázható, hogy 1989 után részben a rendszerváltozás, részben a 2008. évi gazdasági válság olyan jelentős változásokat okozott az egyének gazdasági, társadalmi helyzetében, élet- és munkakörülményeiben, amelyek a lelkiállapot, a lelki egyensúly megbomlásához vezettek. Az elöregedésre, a gazdasági, társadalmi folyamatok további kiszámíthatatlanságára, a jövőbeli bizonytalanságokra tekintettel nem valószínú, hogy a pszichés betegségek százezer lakosra jutó száma csökkeni fog az elkövetkezendő években.

\section{Változások az egészségmutatók megyénkénti rangszámai alapián}

Bár már az egyes indikátorokról különböző időpontokra készült ábrák összevetésével is határozottan kirajzolódtak azok a területek, ahol javult vagy romlott a népesség egészségi állapota, és amelyekből arra is lehet következtetni, hogy hogyan változott a földrajzi megoszlásuk, mégis a területi egységek további vizsgálata (rangsorolás, kategorizálás) is szükséges annak érdekében, hogy olyan jellemzők is a felszínre kerülhessenek, amelyeket a kartografikus ábrázolás esetleg elfedett.

Az egyes indikátorok értékei alapján képzett rangszámok összesítései révén megkaptuk az egyes területi egységek kumulatív rangszámát az adott években. Az 1-től 20-ig terjedő rangszámok közül az 1-es azt jelentette, hogy a vizsgált terület az adott indikátor szempontjából a legkedvezőtlenebb helyzetben van, a 20-as pedig azt, hogy a vizsgált területen az adott indikátor szempontjából a legkedvezőbb a népesség egészségi állapota. Abban az esetben, ha két területi egység indikátorának értéke megegyezett, akkor mind a kettő ugyanazt a rangszámot kapta. (Ez ritkán fordult eló.) Az egyes területi egységek rangszámaiból azt is megtudhattuk, hogy az adott terület népességének az

Területi Statisztika, 2016, 56(5): 483-519; DOI: 10.15196/TS560501 
egészségi állapota hogyan és milyen mértékben változott 1992 és 2014 között. (1. melléklet: A megyék rangszámai néhány fontosabb egészségmutató értékei alapján a rendszerváltozás után).

A vizsgált időszak két fő szakaszra bontható. Az első szakasz a rendszerváltozástól az ezredfordulóig tartott és a második szakasz 2000-től 2014-ig. A két szakaszban a népesség egészségi állapota differenciáltan alakult (3. táblázat).

\section{Néhány egészségmutató kumulatív rangszáma és változásuk mértéke megyénként}

Cumulative rank numbers of some health indicators and

3. táblázat their change by county

\begin{tabular}{|c|c|c|c|c|c|c|}
\hline \multirow{2}{*}{ Megnevezés } & \multicolumn{3}{|c|}{$\begin{array}{l}\text { Néhány egészségmutató } \\
\text { kumulatív rangszáma }\end{array}$} & \multicolumn{3}{|c|}{$\begin{array}{l}\text { Változás mértéke a kumulatív } \\
\text { rangszámok különbsége alapján }\end{array}$} \\
\hline & 1992 & 2000 & 2014 & $\begin{array}{c}1992- \\
2000\end{array}$ & $\begin{array}{c}2000- \\
2014\end{array}$ & $\begin{array}{c}1992- \\
2014\end{array}$ \\
\hline Budapest & 13 & 13 & 19 & 0 & +6 & +6 \\
\hline Pest & 6 & 14 & 17 & +8 & +3 & +11 \\
\hline Fejér & 18 & 19 & 18 & +1 & -1 & 0 \\
\hline Komárom-Esztergom & 8 & 9 & 6 & +1 & -3 & -2 \\
\hline Veszprém & 16 & 18 & 14 & +2 & -4 & -2 \\
\hline Győr-Moson-Sopron & 19 & 20 & 20 & +1 & 0 & +1 \\
\hline Vas & 20 & 16 & 12 & -4 & -4 & -8 \\
\hline Zala & 15 & 14 & 9 & -1 & -5 & -6 \\
\hline Baranya & 8 & 6 & 8 & -2 & +2 & 0 \\
\hline Somogy & 3 & 2 & 4 & -1 & +2 & +1 \\
\hline Tolna & 6 & 11 & 10 & +5 & -1 & +4 \\
\hline Borsod-Abaúj-Zemplén & 4 & 4 & 2 & 0 & -2 & -2 \\
\hline Heves & 10 & 7 & 7 & -3 & 0 & -3 \\
\hline Nógrád & 2 & 1 & 3 & -1 & +2 & +1 \\
\hline Hajdú-Bihar & 17 & 16 & 15 & -1 & -1 & -2 \\
\hline Jász-Nagykun-Szolnok & 11 & 3 & 1 & -8 & -2 & -10 \\
\hline Szabolcs-Szatmár-Bereg & 11 & 11 & 13 & 0 & +2 & +2 \\
\hline Bács-Kiskun & 1 & 5 & 10 & +4 & +5 & +9 \\
\hline Békés & 14 & 10 & 5 & -4 & -5 & -9 \\
\hline Csongrád & 4 & 8 & 16 & +4 & +8 & +12 \\
\hline
\end{tabular}

Megjegyzés: a - jel visszaesést, a + jel előrelépést, a 0 stagnálást jelent.

Az 1990-es évtizedben szinte csaknem megegyezett azon megyék száma, ahol javult vagy romlott az egészségi állapot, míg Budapesten, Borsod-Abaúj-Zemplén és 
Szabolcs-Szatmár-Bereg megye esetében nem változott. Elsősorban a szerényebb mértékủ romlás volt jellemző és csak másodsorban a csekélyebb mértékú javulás. Jobbára egy-két helyet léptek előre vagy hátra a megyék az ezredfordulóig, kivéve JászNagykun-Szolnok megyét, amelynek a pozíciója nyolc helyet esett vissza 2000-re. Szintén kivételként említhető Pest megye, amely nyolc helyet ugrott elóre, ami az egészségi állapot kedvezôbbé válására utal. Ugyancsak említést érdemlő Tolna megye öt hellyel történő előretörése is. Mindezek azzal magyarázhatók, hogy az adott megye gazdaságában és társadalmában olyan kedvező vagy kedvezőtlen változások vették kezdetüket vagy gyorsultak fel 1989 után, amelyek a népesség egészségi állapotát kifejező indikátorokat (például halálozások) is érintették valamilyen mértékben. Számos kutatás azt igazolta, hogy a rendszerváltozás után a lakosság egészségi állapota több szempontból is romlott, mert nőtt a munkanélküliség, a szegénység és rosszabbak lettek az életkörülmények stb. S ez nemcsak hazánkban volt megfigyelhető, hanem más posztszocialista országban is (Dumitrache-Armas 1998, Dzúrová-Dragomirecká 1997, Szilágyi-Uzzoli 2013). A szocializmus összeomlása, a szabadság eufóriája, a határok megnyílása, a lehetőségek kiszélesedése stb. viszont a lelki egészségre kedvezően hatott, legalábbis a rendszerváltozás utáni években (Elekes-Paksi 1996).

Az ezredforduló után a megyék egészség szerinti rangsorában jelentősebb változás nem következett be. Eggyel kevesebb lett a stagnáló egészségi állapotú terület, és a korábbi évtizedhez képest eggyel bővült azon megyék köre, amelyek pozíciója roszszabb lett.

A legnagyobb mértékben Csongrád, Budapest és Bács-Kiskun megye pozíciója javult $(8,6$, illetve 5 hellyel), amibe az előbbi kettőnél a diplomások növekvő (2011-re 18,7, illetve 34\%-ot elérô) hányada, az utóbbinál az autóipar felfutása is releváns szerepet játszhatott. Ugyanakkor a legnagyobb mértékben Zala és Békés megye rangsorban elfoglalt helye romlott, mert egyaránt 5 hellyel estek vissza, majd Vas és Veszprém megye következett egyaránt 4 hellyel, amiért több tényező is (például a népesség elöregedése, az országos átlagnál kisebb diplomásarány és egy főre jutó havi bruttó átlagkereset, az elaprózott településszerkezet, az egészségügyi ellátásból fakadó gondok stb.) okolható. Például 2014-ben Veszprém megye kivételével mind a három másik említett megyében az országos átlagtól elmaradt a diplomások aránya, ellenben a munkanélküliségi ráta Zala és Békés megyében meghaladta azt.

Az 1992. évi és a 2014. évi rangszámok összevetésével azt mutatjuk be, hogy ténylegesen hogyan alakult az egyes területi egységekben a népesség egészségi állapota a rendszerváltozástól napjainkig. Abból, hogy a vizsgált területi egységek közül ugyanannyinak javult, illetve romlott a pozíciója, arra következtethetünk, hogy a népesség egészségi állapota nem változott lényegesen. A valóság viszont az, hogy a rangszámváltozás mértéke nagyon jelentős volt a legtöbb megyében. Ennél fogva a népesség egészségi állapota gyökeresen megváltozott pozitív vagy negatív irányba. Az elmúlt évtizedekben az egészségi állapot legnagyobb mértékben Csongrád és Pest megyében javult, mert 12, illetve 11 hellyel léptek előre, mialatt Jász-Nagykun-Szolnok

Területi Statisztika, 2016, 56(5): 483-519; DOI: 10.15196/TS560501 
megye 10, Békés megye 9 és Vas megye 8 hellyel esett vissza a rangsorban, feltehetően a már előzőekben említett okok miatt. Rajtuk kívül még Budapest és Zala megye pozíciója változott nagyobb mértékben, mert az előbbi 6 hellyel előrébb, az utóbbi 6 hellyel hátrébb került. A többi megye rangszámában ennél szerényebb mértékủ a változás. Általánosságban megállapíthatjuk, hogy míg az elmúlt 25 év alatt a fővárosban és Pest megyében, valamint Dél-Dunántúl és Dél-Alföld megyéiben - Békés kivételével - javult az egészségi állapot, addig az ország többi részében romlott.

Borsod-Abaúj-Zemplén és Heves megye pozíciójának romlása a rendszerváltozás utáni kedvezőtlen gazdasági (például ipar leépülése) és társadalmi folyamatokkal (például munkanélküliség növekedése) magyarázható. A munkanélküliek aránya 1992-ben és 2014-ben is a következő megyékben volt magasabb az országos átlagnál (8,2 és 7,7\%): Borsod-Abaúj-Zemplén (13,1 és 11,3\%) és Heves megyében (10,2 és 9,9\%). Az viszont, hogy Közép-Dunántúl nyugati részének (Veszprém, Komárom-Esztergom megye) és Nyugat-Dunántúl déli részének (Vas, Zala megye) romlott a helyzete nem magyarázható az előbb említett okokkal. Hiszen ezek a térségek a rendszerváltozás nyertes térségei, ahol az ipari átstrukturálódás rövid időn belül lezajlott, és a külföldi tőkének köszönhetően számos új vállalkozás jelent meg (Kiss 2010). Feltételezhetô tehát, hogy egyéb, úgymond „lokális”, a „hely” sajátos társadalmi, gazdasági jellemzőiből eredő okai lehetnek annak, hogy romlott lakosságuk egészségi állapota.

Mindössze két megyének sikerült megőriznie 1992. évi pozícióját 2014-re is. Közülük az egyik Fejér megye, amely 18. helyével mindvégig az élvonalban volt. Ezzel szemben Baranya megye a 8 . helyével a rosszabb egészségi állapotú területek közé sorolható, tulajdonképpen a középmezőny „alján” foglalt helyet. Ennek magyarázata szintén további kutatásokat igényel.

A rangsorváltozások egyúttal azt is jelzik, hogy az elmúlt évtizedekben némileg átrendeződött a jobb vagy a rosszabb egészségi állapotú területek térbeli megoszlása. A rendszerváltozás kezdetén „egységesen” jó vagy kevésbé rossz egészségi állapotú régiókon (például Közép- és Nyugat-Dunántúl, Észak-Alföld) belül jelentős differenciálódás ment végbe, a különbségek nőttek, ezzel szemben például Közép- és ÉszakMagyarországon mérséklődtek.

Az 1992. és a 2014. évi rangszámok egymáshoz viszonyított változása alapján képzett kategóriák révén a változás irányát és mértékét is meg lehet határozni, a kategóriák ábrázolásával pedig annak területi megnyilvánulását (10. ábra).

Az egyes kategóriákba tartozó területi egységek a térben kevésbé alkotnak összefüggő területet, többnyire szórtan fordulnak elő. Az azonban jól kivehetó, hogy az ország központi és középső részében, a Duna-Tisza közén és Dél-Dunántúlon javulás jellemző 1992 és 2014 között, mellyel egyidejűleg az ország többi részében (kivéve a stagnálókat) pozícióromlás. Kedvezőtlenebb helyzetbe került a Dunántúl középső és nyugati része (Veszprém, Vas, Zala megye) és Komárom-Esztergom megye, valamint a Tiszántúlon Jász-Nagykun-Szolnok, Békés és Hajdú-Bihar megye, továbbá ÉszakMagyarországon Heves és Borsod-Abaúj-Zemplén megye.

Területi Statisztika, 2016, 56(5): 483-519; DOI: 10.15196/TS560501 
A megyék pozíciójának 1992 és 2014 közötti változása

10. ábra néhány fontosabb egészségmutató kumulatív rangszáma alapján

The change of the position of counties by the cumulative rank numbers of selected health indicators, 1992-2014

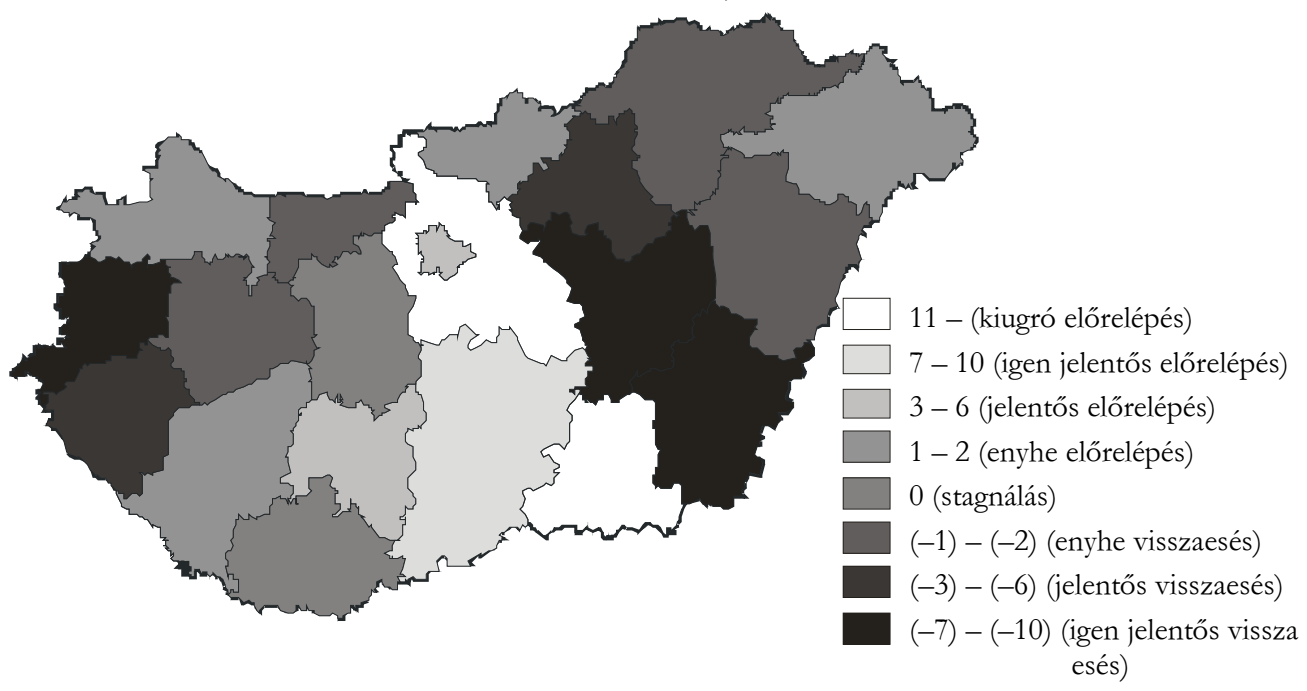

A rangszámok elemzését úgy is elvégeztük, hogy az egészségmutatók közül kivettük a morbiditási mutatót (pszichiátriai gondozottak százezer lakosra jutó száma) annak érdekében, hogy feltárjuk az esetleges „torzító” hatását. Az egyes megyék kumulatív rangszámai alig változtak, általában egy-két hellyel különböztek az előzô vizsgálatok rangszámaitól, tehát alapvetően nem ,írták felül” az azokban feltárt változásokat. A morbiditási mutató nélkül csak Csongrád megyében javult jóval kisebb mértékben az egészségi állapot, ami valószínúleg a pszichiátriai ellátórendszer releváns fejlődésével függött össze, ugyanis a gondozottak tízezer lakosra jutó száma jelentősen csökkent 1992 és 2014 között. Egyébként a főbb trendek hasonlóak. A különbség lényegében csak a változás intenzitásában van. A térbeli átrendeződés pedig követi az összes egészségindikátor által alkotott térbeli mintázatot (2. melléklet: Néhány fontosabb egészségmutató kumulatív rangszáma és változásuk mértéke és $\underline{3 \text {. mel- }}$ léklet: A megyék pozíciójának 1992 és 2014 között változása néhány fontosabb egészségmutató kumulatív rangszáma alapján).

\section{Összefoglalás}

A rendszerváltozás óta a magyar népesség - nemzetközi összehasonlításban évtizedek óta igen kedvezőtlen - egészségi állapotában jelentős és térben differenciált változá-

Területi Statisztika, 2016, 56(5): 483-519; DOI: 10.15196/TS560501 
sok következtek be. Az egészségegyenlőtlenségek különböző okokra vezethetők viszsza, amelyek között az egyéni adottságok mellett az utóbbi időben egyre nagyobb szerepet kapnak a társadalmi tényezők. A néhány fontosabb egészségmutató három (1992, 2000, 2014) időpontban és megyei szinten történt vizsgálata alapján megállapítható, hogy a népesség egészségi állapotában a területi különbségek (egy-két mutató kivételével) nőttek az elmúlt évtizedekben, a differenciáltabb társadalmi, gazdasági fejlődéssel összefüggésben.

A különbségek térbeli mintázata is módosult. Mindössze két (Fejér, Baranya) megyének sikerült 1992. évi pozícióját megőriznie 2014-re is. Rajtuk kívül még Győr-Moson-Sopron, Komárom-Esztergom, Veszprém, Somogy, Hajdú-Bihar, Szabolcs-Szatmár-Bereg, Borsod-Abaúj-Zemplén és Nógrád megye pozíciója csak kismértékben változott, ami a különbségek földrajzi állandóságára, tartósságára utal. Az örökölt területi differenciák tehát úgy tủnik, hogy ezen megyék esetében tartósan meghatározzák az egészségi állapot elmúlt évtizedekben kimutatott különbségeit. Ugyanakkor a többi vizsgált területi egység helyzetében jelentős változások következtek be, ami térbeli átrendeződést eredményezett.

Az 1990-es évektôl napjainkig az egyik leglényegesebb változás, hogy a tartósan legjobb egészségi állapotú Győr-Moson-Sopron, Fejér megyéhez csatlakozott Budapest és Pest megye, mintegy „eltolódás” következett be az ország központi része javára. Budapest helyzetének javulása nem szorul különösebb magyarázatra, hiszen nagyon sok lényeges egészségi állapotot befolyásoló tényezőjének értéke kedvező vagy kedvezőbbé vált 1989 után. Ezzel szemben Pest megye előretörése elsődlegesen az 1990-es években felerősödött szuburbanizáció következménye, miáltal előnyösebbé vált például a korstruktúra és az iskolázottsági szint is. A másik releváns változás, hogy a legrosszabb egészségi állapotú területek köre is módosult a vizsgált időszakban. Amíg 1992-ben Bács-Kiskun, Nógrád és Somogy megye állt az élen, addig 2014-ben már Jász-Nagykun-Szolnok és Borsod-Abaúj-Zemplén megye. A pozícióján javító Nógrád megye továbbra is a legrosszabb egészségi állapotú területek egyike. Nagyfokú stabilitása számos kedvezőtlen mutatójának (például magas munkanélküliség, a diplomások alacsony aránya, alacsony átlagkereset) eredője. Borsod-Abaúj-Zemplén megyében az 1989 utáni hatalmas gazdasági és társadalmi változások okozták elsősorban az egészségromlást. Nagy kérdés viszont Jász-Nagykun-Szolnok megye élre kerülése, mert több mutatójának értékéből (például öregedési index, munkanélküliségi ráta, egy főre jutó GDP) nem következik ez a nagyon rossz helyzet, még ha a diplomásainak az aránya (13\%) és az egy főre jutó havi bruttó átlagkereset összege (184 ezer forint) is sokkal alacsonyabb az országos átlagnál. Részben éppen ezért is további „helyi szintű”, empirikus kutatások szükségesek a különbségek területi mintázatában kimutatható változások minél pontosabb megismeréséhez. 


\section{IRODALOM}

AMBrus, Z.-VARSÁNYI, T. (2011): Az egészség és az életmód regionális különbségei Területi Statisztike 51 (3): 227-244.

ANTAL, M.-PÉTER, SZ. (2016): Táplálkozás és légszennyezettség Egészségtudomány 60 (1): $47-56$.

BÁLINT, L. (2008): Öngyilkosságok Magyarországon - néhány területi jellegzetesség Területi Statisztika 48 (5):573-592.

BolAm, B.-MurPHY, S.-GLEESON, K. (2006): Place-identity and geographical inequalities in health: A qualitative study Psychology and Health 21 (3): 399-420.

Botan, C. N. (2011): Public health in Maramures County - Current status, problems and strategies Studia Universitatis Babes-Bolyai Geographia 56 (1): 215-231.

BÖCKERMAN, P.-IlmaKUNNAS, P. (2008): Unemployment and self-assessed health: evidence from panel data Health Economics 18 (2):161-179.

CORNIA, G. A.-PANICIA, R. (eds.) (2000): The mortality crisis in transitional economies Oxford University Press, Oxford.

DAhlgREEN, G.-WHiteHEAD, M. (2006): European strategies for tackling social inequalities in health: Levelling up Part 2. WHO Regional Office for Europe, Copenhagen.

Dumitrache, L.-ARMAS, I. (1998): The health state of the Romanian population during the transition period Geojournal 44 (2):151-160.

DZúrovÁ, D.-DragomireCKÁ, E. (1997): Social transformation and mental health: The Czech Republic after 1989 Acta Universitatis Carolinae (32):179-189.

EGRI, Z. (2012): Az egészségi állapot, mint a (területi) fejlettség eredmény indikátora Valóság 55 (10): 22-57.

ELEKES, Zs.-PAKSI, B. (1996): Lelkünkre ül-e a politika? Az öngyilkosság és az alkoholizmus változó trendjei? Századvég 1 (2):103-116.

ENYEDI, GY. (1993): Társadalmi-területi egyenlőtlenségek és területi politika Magyarországon In: ENYEDI, GY. (szerk.): Társadalmi-területi egyenlötlenségek Magyarországon pp. 9-23., Közgazdasági és Jogi Könyvkiadó, Budapest.

FARAGÓ, M. (2007): Egészségesen várható élettartamok Magyarországon, $2005 \mathrm{KSH}$, Budapest.

FÖLDI, K. (2007): Változások az alapvető élelmiszerek fajlagos fogyasztásában Magyarországon Szolnoki Tudományos Közlemények (11): 1-31.

GIDAI, E. (2010): A népesség egészségi állapotának várható alakulása 2025-ig In: NOVÁKY, E. (szerk.): Magyarország 2025 pp.157-169., Gazdasági és Szociális Tanács, Budapest.

HAMilton, F. E. I. (1995): Re-evaluating space: locational change and adjustment in Central and Eastern Europe Geographische Zeitschrift 83 (2): 67-86.

Jones, K.-MoOn, G. (1987): Health, disease and society: A critical medical geography Routledge and Kegan Paul Ltd., Portsmouth Politechnic, London-New York.

JÓZAN, P. (2008): Válság és megújulás a második világháború utáni epidemiológiai fejlódésben Magyarországon MTA Társadalomkutató Központ, Budapest.

KeARns, R.-MoOn, G. (2002): From medical to health geography: novelty, place and theory after a decade of change Progress in Human Geography 26 (5): 605-629.

KISS, É. (1993): Az egészségi állapot néhány jellemzője a Közép-Tiszavidék elmaradott térségében Népegészségügy 74 (1): 22-31.

Területi Statisztika, 2016, 56(5): 483-519; DOI: 10.15196/TS560501 
KISs, É. (2005): Egészségi állapot és egészségpolitika In: KISS, É. Az Európai Unió a XXI. száąad elején pp. 245-254., Akadémiai Kiadó, Budapest.

KISS, É. (2010): Területi szerkezetváltás a magyar iparban 1989 után Dialóg Campus Kiadó, Budapest-Pécs.

KISS, I.- SÁNDOR, J.-NAGYMAJTÉNYI, L.-EMBER, I. (2003): A daganatos halálozások regionális és megyei megoszlása Magyarországon In: ÁDÁNY, R. (szerk.): A magyar lakosság egészségi állapota az ezredfordulón pp. 111-121., Medicina Könyvkiadó Rt., Budapest.

Kopp, M. (2003): A mentális és magatartási betegségek és zavarok gyakorisága és az általuk okozott társadalmi teher In: ÁDÁNY, R. (szerk.): A magyar lakosság egészségi állapota az ęredfordulón pp.191-207., Medicina Könyvkiadó Rt., Budapest.

Kopp, M.-MARTOS, T. (2011): A magyarországi gazdasági növekedés és a társadalmi jóllét, életminöség viszonya Magyar Pszichofiziológiai és Egészséglélektani Társaság, Budapest.

KOPP, M.-SKRABSKI, Á. (2001): Az egészségi állapot társadalmi, magatartási, életmódbeli meghatározói Eqredforduló (4):14-18.

Kopp, M.-SKRABSKI, Á. (2007): A magyar népesség életkilátásai Magyar Tudomány 168 (9): 1149-1153.

KOZÁK, Á. (2009): Táplálkozás, fogyasztás és életmód a rendszerváltozás utáni Magyarországon Élelmiszer, Táplálkozás és Marketing 6 (1-2): 19-23.

KSH (2009): Légzőszervi megbetegedések Statisztikai Tükör 3 (44): 1-3.

KSH (2010): Társadalmi belyzetkép KSH, Budapest.

KSH (2015): Európai lakossági egészségfelmérés, 2014 Statisztikai Tükör 29 :1-9

LALOnde, M. (1974): A new perspective on the health of Canadians: a working document Ministry of Supply and Services, Canada, Ottawa.

MAKARA, P. (1997): Társadalmi-területi egyenlőtlenség az egészségi állapotban, az egészségügyben $A$ falu 12 (3): 49-53.

MiLTÉNYI, K. (1991): A népesség egészségi állapota; demográfiai, társadalmi-kulturális és életmódbeli összefüggések Demográfia 34 (1-2): 151-179.

Oliver, S.-Kavanagh, J.-CAird, J.-Lorenc, T.-Oliver, K.-Harden, A.-Thomas, J.Greaves, A.-OAKLEY, A. (2008): Health promotion, inequalities and young people's bealth. A systematic review of research Report No. 1611., EPPI-Centre. Institute of Education, University of London, London.

PÁL, V. (2013): A perifériahelyzet és az egészségi állapot: egy ormánsági kutatás tapasztalatai A falu 28 (1): 29-40.

PÁL, V.-Uzzoli, A. (2008): Az emberiség egészsége - a 21. század kihívásai Földrajzi Közlemények 132 (4):471-488.

PÁL, V.-UzZOLI, A. (2013): A világ egészségföldrajza In: EMBER, I.-PÁL, V.-TÓTH, J. (szerk.): Egészségföldrajz. pp. 135-153., Medicina Könyvkiadó Zrt, Budapest.

PAulik, E. (szerk.) (2014): Megelőzőo orvostan és népegészségtan JATE Press, Szeged.

Platon, V.-COnstantinescu, A. (2013): Regional disparities in Romania. Contribution of the Regional Operational Program to health infrastructure Romanian Review of Regional Studies 9 (2): 87-98.

SCHMIDT, P.-SIMON, T.-KAPPÉTER, I. (2010): Lelki betegek és deviánsok helyzete és ellátása 2025-ben In: NovÁKY, E. (szerk.): Magyarorsqág 2025 pp. 199-214., Gazdasági és Szociális Tanács, Budapest.

Területi Statisztika, 2016, 56(5): 483-519; DOI: 10.15196/TS560501 
SmYTH, F. (2008): Medical geography:understanding health inequalities Progress in Human Geography 32 (1): 119-127.

SZILÁGYI, D.-UZZOLI, A. (2013): A nyugat-kelet és a centrum-periféria relációk a hazai egészségegyenlőtlenségek alakulásában az 1990 utáni válságok idején Magyarországon Területi Statisżtika 53 (4): 306-322.

Uzzoli, A. (2003): A magyar népesség egészségi állapota az európai országok körében. Földrajzi Közlemények 51 (1-4): 131-156.

UzzoLI, A. (2008): Az egészségi állapot világméretű különbségei Földrajz̨i Értesitő 57 (3-4): 399-415.

Uzzoli, A. (2010): Az egészségi állapot területi különbségei Magyarországon In: MEZEI, I.BARABÁs, D. (szerk.): Földrajz̨ szemelvények határok nélküll pp. 73-77., MTA RKK, Pécs.

UzZOLI, A. (2012): Connection between health inequalities and the recent economic crisis in Hungary In: Társadalomföldrajzi kibivások a XXI. sqáaad Kelet-Közép-Európájában pp. 429-436., II. Rákóczi Ferenc Kárpátaljai Magyar Főiskola, Beregszász.

Uzzoli, A.-Vitrai, J.- BAKAcs, M.-GÉmes, K.-Kiss, N.-KÖVI, R. (2011): A lakóhelytől függ az esély a jobb minőségű ellátásra. Az ellátáshoz való hozzáférés területi egyenlőtlenségei Magyarországon a szürkehályogmútétek példáján Tér és Társadalom 25 (2): 88-105.

VEenstra, G. (2005): Location, location, location: contextual and compositional health effects of social capital in British Columbia, Canada Social Science \& Medicine 60 (9): 2059-2071.

\section{INTERNETES HIVATKOZÁSOK}

EUROPEAN PARLIAMENT (2010): Alcohol: the risk of excessive consumption http://www.europarl.europa.eu/news/en/news-

room/20150424STO46092/Alcohol-the-risks-of-excessive-consumption (letöltve 2016. június)

Hamilton, N.-BhatTi, T. (1996): Population health promotion: an integrated model for population bealth and health promotion Health Promotion Development Division, Ottawa. (http://www.phac-aspc.gc.ca/ph-sp/php-psp/index-eng.php) (letöltve 2016. június)

Területi Statisztika, 2016, 56(5): 483-519; DOI: 10.15196/TS560501 